
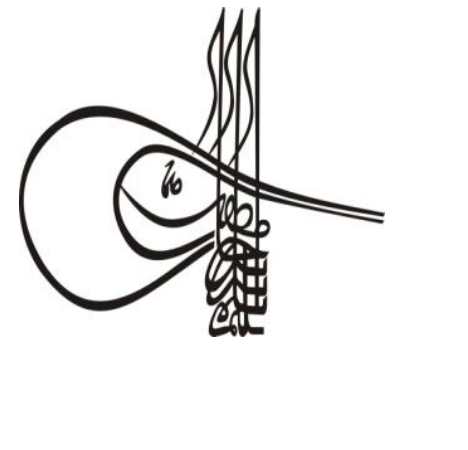

Received/Geliş: 10.11 .2019

Go Report Dates/Rapor Tarihleri: Referee 1 (26.11.2019)-Referee 2 (15.12.2019)

\section{Tutkigh Studies \\ Social Sciences}

Volume 14 Issue 6, 2019, p. 3131-3155

DOI: 10.29228/TurkishStudies.39680

ISSN: 2667-5617

Skopje/MACEDONIA-Ankara/TURKEY
Research Article / Araştırma Makalesi

Article Info/Makale Bilgisi

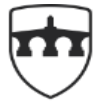

INTERNATIONAL

BALKAN

UNIVERSITY

EXCELLENCE FOR THE FUTURE IBU.EDU.MK

VAccepted/Kabul: 20.12.2019

This article was checked by intihal.net.

\title{
19. YÜZYIL İNGİLİZ GEZGİN-SANATÇILARININ GRAVÜRLERİNDE “KUDÜS” *
}

\author{
Eylem GÜZEL $L^{* *}$ - Necla ARSLAN SEVIIN ${ }^{* * *}$
}

\begin{abstract}
öz
Batılllar için 15. yüzyıldan itibaren bir ilgi ve merak kaynağı olan Osmanlı İmparatorluğu, özellikle 18. yüzyılın sonu ve 19. yüzyılda Avrupa'da gerçekleşen Fransız Devrimi, Romantizm, Oryantalizm ve Arkeoloji biliminin gelişmesi gibi olaylar sonucunda Batılı seyyahların uğrak yeri haline gelmiştir. Başta İstanbul olmak üzere imparatorluğun dört yönündeki belli başlı merkezlere yapılan bu seyahatlerde gerçekleştirilen resimler, tutulan günlükler, alınan notlar ve buralardan yazılan mektuplar, gezginler ülkelerine döndükten sonra albüm ya da seyahatname olarak basılmıştır. Bu merkezlerden en önemlisi, kuşkusuz ki üç Semavi din için kutsal kabul edilen Kudüs'tür. Doğu'yu ziyaret eden, Kudüs ve Kutsal Topraklar'a giden Hristiyan sanatçılar arasında en kalabalık grubu İngilizler oluşturmaktadır. Aralarında W. H. Bartlett, D. Roberts, T. Allom, J. D. Woodward gibi isimlerin bulunduğu İngilizler, Kudüs ile ilgili gerçekleştirdikleri ve sonradan gravüre dönüştürülen resimlerle bu Kutsal Kenti batı insanına tanıtmayı amaçlamışlardır.

Uzun yolculukları sonrasında Kudüs'e ulaşan gezgin sanatçılar, öncelikle, kenti uzaktan ve panoramik görünümüyle algilarlar. Bu görüntülerde kent, surların gerisinde, Haremi Şerif'in içinde yer alan Mescid-i Aksa Camii ve Kubbet-üs Sahra gibi yapiların vurgulandığı kareler olarak verilmiştir. Sanatçıların Kudüs gözlemleri İncil'de konu edilen Zeytin Dağı ile başlayıp Hz. İsa'nın yaşamından izleri barındıran
\end{abstract}

\footnotetext{
* Çalışma, 2. Uluslararası Sosyal Bilimler Kongresi (International Congress on Social Sciences II) (INCSOS 2018) (Kudüs 2017) bildiri olarak sunulmuştur. Araştırma konusu genişletilip geliştirilerek yayın olarak hazırlanmıştır. The Study was presented as a notice in International Congress on Social Sciences II (INCSOS 2018) (Jerusalem 2017). Prepared as a publication by expanding and further developing the research subject
}

** iD Doç. Dr., Bandırma Onyedi Eylül Üniversitesi, E-posta: eyl2@ hotmail.com 
Getsemani Bahçesi, Via Dolorosa (Çile Yolu) gibi yerlerle devam etmektedir. Geniss bir konu perspektifine sahip olan gravürlerin çoğunlukla belgeleyici bir kaygiyla ele alındığı dikkat çekmektedir. Bununla birlikte bazı örneklerde abartılı ifadelere yer verildiği görülmektedir. Ayrıca çalışmalarda Romantik ve Oryantalist eğilimler de dikkati çekmektedir.

$\mathrm{Bu}$ çalışma, Kudüs'ü konu eden gravürler üzerinedir. Çalışmamızda, İngiliz sanatçıların Kudüs'e bakış açıları ve gravürlerinde kenti yansıtma biçimleri ele alınmıştır.

Anahtar Kelimeler: Kudüs, Gravür, Oryantalist Resim, Kutsal Topraklar

\title{
“JERUSALEM" IN THE ENGRAVINGS OF 19TH CENTURY BRITISH TRAVELER-ARTISTS
}

\begin{abstract}
Having been a source of interest and curiosity for Westerners since the 15th century, the Ottoman Empire became a popular destination for Western travelers, particularly as a consequence of the events taking place in the late 18th century and in the 19th century such as French Revolution, Romanticism, Orientalism and the development of Archeology science. The pictures drawn, the notes taken, the diaries kept, and the letters written during these trips to major centers in the four directions of the empire, particularly Istanbul, were published as albums or travel books after the travelers returned to their countries. Being regarded as sacred for the three divine religions, Jerusalem is beyond question the most important of these centers. Among the Christian artists who travelled to the East and visited Jerusalem and the Holy Land, there were primarily the British. The British, including W. H. Bartlett, D. Roberts, T. Allom, J. D. Woodward, aimed to introduce this Holy City to the western people via the pictures they drawn about Jerusalem and the engravings converted from the pictures later.

The traveller artists who arrive to Jerusalem after a long journey first perceive the city from afar and with a panoramic image. In these images, behind the city walls, the buildings of the Masjid al-Aqsa Mosque and Kubbet al-Sahra, which are located in the Haremi Sharif, are given as squares that are emphasized. The Jerusalem observations of the artists started with Mount of Olives referred in Bible and continued with places such as Via Dolorosa (The Way of the Cross) and Garden of Gethsemane which bears the traces of the life of the Jesus Christ. It is remarkable that gravures, which have a broad subject perspective, are mostly addressed with documentor concern. In addition, in some cases, exaggerated expressions are included. Also, Romantic and Orientalist tendencies draw attention.

This study is on the engravings about Jerusalem. In this study, the perspectives of British artists on Jerusalem and how they reflect the city in their engravings were discussed.
\end{abstract}




\section{STRUCTURED ABSTRACT}

The traveller artists who arrive to Jerusalem after a long journey first perceive the city from afar and with a panoramic image. The strategic position of the city, being surrounded by valleys and mountains and its interesting layout, make it worth to paint the city for artists. The panorama of the city was painted by looking at to Mount of Olives particularly and to other hills on the entrance. David Roberts is one of the top travellers to enjoy the city from a high point of view. In his lithography, Jerusalem from the Mount of Olives, a view from the eastern side of the city (from the Mount of Olives) is reflected.

The main theme of the observations of travellers visiting Jerusalem about the city is the part known as Old (Antique) Jerusalem. In these images, behind the city walls, the buildings of the Masjid alAqsa Mosque and Kubbet al-Sahra, which are located in the Haremi Sharif, are given as squares that are emphasized. These buildings as emphasized in the general images appear in the examples where the architecture of the city is discussed in detail. It is seen that the building works are carried out with great care and especially the architectural elements and ornaments are reflected in detail. Masjid al-Aqsa Mosque in Haremi Sharif and Al Aqsa Mosque of J.D. Woodward was processed in wood printing of Jerusalem. In the example taken with a detailed understanding, the structure is located behind the olive tree, one of the symbols of Jerusalem. The two figures standing in the shade of the tree and the two other worshipers next to them, the entrance facade where the last five-eyed congregation place is depicted.

The Jerusalem observations of the artists started with Mount of Olives referred in Bible and continued with places such as Via Dolorosa (The Way of the Cross) and Garden of Gethsemane which bears the traces of the life of the Jesus Christ. In this journey following the Bible's narratives, the Church of Kamame has received most attention without doubt. The building,with its outer and inner view, is presented to the audience. The structure, which is frequently used in gravures, is also found on the book covers of travelers. The lithography named The Entrance to the Church of the Holy Sepulcher, by the traveling artist D.Robert, is a good example. Another gravure that the church is concerned belongs to W.H. Barlett. In the gravures of the Church of the Holy Sepulcher, the building is depicted with crowded human figures in front of it. Among the religious buildings, the Jewish Wailing Wall, also known as the Western Wall, is one of the most popular. The Jewish Weeping Place which belongs to William Henry Barlett, was painted in gravure of Jerusalem while a group of men and women was worshipping. Another group of building that does not escape from attention in Jerusalem is the entrance gates of the city walls surrounding the city. Buildings such as Damascus Gate and Golden Gate were reflected in the gravures of the artists. Damascus Gate by D. Roberts, depicts the most magnificent Damascus Gate among the seven gates of the city. Another building group that attracted the attentions while visiting the city is the water structures. One of the most spectacular of these structures engraved in numerous gravures is the Kayıtbal Sebili (çevirmen notu: bunun ingilizcesini bulamadık biliyorsanız bizimle paylaşabilirsiniz.), dated 1482 of the Mamluk Sultan, known as the Kayıtbal Sebili. The square-shaped building, Onion Dome and

\section{Turkish Studies - Social Sciences}

Volume 14 Issue 6, 2019 
ornaments seen in the wood print of the West Side of the Harem-i Sharif by J.D Woodward bear the traces of Mamluk art. The artists who visited the city engraved street image scenes and daily life that took place in the street. In another work called Street Coffee, Jerusalem, Harry Fenn depicts a bedouin and the villagers playing checkers. It is seen that travellers travelling on the territory of Jerusalem are also interested in houses and streets. This interest has been shown to the exterior architecture and street layout of the houses as well as the life in them. In the gravure of the House of a Christian Family in Jerusalem, owned by W.H. Barlett, the inhabitants of the house are depicted in a large arched and domed interior. Oriental home culture; embroidered coffee tables, floor cushions and sliced arched windows are given in details. It is a product of great observation and labour that the artist has reflected this place in all details with its rich stone and wood workmanship. Land.

Keywords: Jerusalem, Engraving, Orientalist Painting, The Holy

\section{Giriş}

Osmanlı İmparatorluğu toprakları, 15. yüzyıldan itibaren Batılılar için bir merak ve ilgi kaynağı olmuştur. Başlangıçta diplomat ve tüccarlarla Osmanlı topraklarına gelen sanatçı ve bilim adamlarının sayısı 18. ve 19. yüzyıllarda giderek artmıştır. İlk dönemler İstanbul, daha sonraki süreçlerde imparatorluğun dört yöndeki sınırlarına kadar belli başlı merkezler gravür ve seyahatnamelere konu olmuştur (Arslan Sevin, 2006, 36; Arslan, 1992: 15; Germaner-İnankur, 1989: 11; Taşçıkar; 2002: 5; Güzel, 2010: 19-20; Germaner, 1992:105). Romantizm ve Oryantalizmin etkisiyle 19. yüzyılda, kendilerini büyülü Doğu kavramına kaptıran Batılılar, genelde Doğu özelde de Osmanlı İmparatorluğu ile yakın ilişki içerisine girmişlerdir. Farklı meslek gruplarından oluşan çok sayıda Batılı gezgin, bu dönemde Osmanlı topraklarına ziyarette bulunmuşlardır. Bu geziler bir yandan anlatım olarak seyahatnamelerde yer almakta, diğer yandan da Oryantalist resimler olarak Batı'ya taşınmaktadır (Arslan Sevin, 2006, 36, Kabbani, 1993: 35 Parla, 2005: 36-37; Germaner-İnankur, 2002: 41).

Batılı gezginler için Osmanlı İmparatorluğu topraklarında ilgi odağı olan kentlerin en önemlilerinden biri de Kutsal Topraklar'da yer alan Kudüs'tür. Kentin üç semavi din için sahip olduğu kutsiyeti, hiç kuşkusuz bu durumun en temel nedenidir. Kudüs, İslamiyet, Hristiyanlık ve Musevilik için kutsal bir şehirdir; Yahudiler için Rabb'ın dünyayı yaratmaya başladığı yer; Hristiyanlar için mahşerin, dirilişin mekânı; Müslümanlar için ilk kıble ve Mirac'ın basamă̆ 1 olması gibi sayısız ulvi hatıraları ve mucizeleri bağrında taşımaktadır (Çift-Harman, 2017:7; Harman, 2002:323-327).

Dünyanın en eski yerleşimlerinden biri olan Kudüs, Tunç ve Demir çağlarından itibaren, Yunan, Roma, Bizans, Haçlılar, Emevi, Abbasi, Fatımi, Eyyubi, Memluk ve Osmanlı dönemlerinde ortaya çıkıp günümüze kadar uzanan medeniyet izlerini bünyesinde barındıran bir kenttir. Tarih boyunca Ursalim, Yeruşalim, Yebus, İlya, Kapitolina, El-Medine, Beytü'l-Makdis ve Kudüs gibi farklı isimlerle bilinen kent, ünlü surlarıyla, özgün durumunu iyi muhafaza edebilen Ortaçağ şehirlerinden biri sayılmaktadır. Müslüman, Hristiyan, Ermeni ve Yahudi mahallesi olmak üzere dört mahalleden oluşan kadim Kudüs, birçok kültürün vatanı olmuş ve bu durum şehrin mimari planlamasına, kutsal binalarına, yollarına, çarşılarına ve dingin mahallelerine yansımıştır. Kudüs'teki mahalle gelenekleri günümüzde de korunmaktadır. Bu kadim geleneği ile Kudüs, insanlık tarihinin nabzının attığı bir coğrafya olmuş ve 1982 yılında Ürdün Krallığı aracılığı ile

\section{Turkish Studies - Social Sciences}

Volume 14 Issue 6, 2019 
tehlike altında bulunan dünya şehirleri mirası listesine eklenmiştir (Filistin Rehberi, t.y.: 4; Montefiore, 2016).

\section{19. Yüzyıl İngiliz Gezgin-Sanatçılarının Gravürlerinde "Kudüs"}

Kadim Kudüs kenti, her dönem için dini ve sosyo-kültürel açıdan birçok gezgin sanatçıyı kendine çekmeyi başarmıştır. Önceleri haç ziyareti için giden Hristiyan Hacılara 18. ve 19. yüzyıllarda çok sayıda gezgin-sanatçı da eklenmiştir. Bu sanatçılar arasında önemli bir grubu İngilizler oluşturmaktadır. Sanatçılar Kudüs ile ilgili çok sayıda gravür yaparak kentin dini ve sosyal kimliğini ve bu kimliği yansıtan mimari yapılarını Batı'ya taşımışlardır (Lancaster, "Jerusalemin 19th Century Art" http://www.coastdaylight.com/prints/print-c8129.html Erişim Tarihi: 24.02.2018; Dağdelen, 2018; Stebbing, 1847; Wilson, 1881). Kudüs kenti, ünlü surlarıyla, özgün kimliğini iyi muhafaza edebilen Ortaçağ şehirlerden biri olarak, sanatçılara elverişli bir olanak sunmaktadır (Bkz. Vesika ve Fotoğraflarla Osmanlı Devrinde Kudüs 2, 2011)

Kudüs'e yaklaşan gezginler kentin sağladığı manzara karşısında oldukça etkilenirler. Uzun yolculuk sonrasında nihayet kenti fark ettikleri zaman, öncelikle, uzaktan ve genel görünümünü algılarlar. Kentin stratejik konumu, dağ ve vadilerle çevrili oluşu ve ilginç yerleşim düzeni, burayı sanatçılar için resmedilmeye değer kılmıştır. Kudüs'ün ilginç yerleşim düzeni ve Sahra Moriya Dağı'nda (Seçilmiş Dağ) konumlanışını gösteren en güzel örneklerden biri, David Roberts'a ait olan Kudüs'ün Güneyden Görünüşü adlı gravürdür (Foto. 1). Litografide, şehir, özel bir tasvirden çok çevresindeki tüm doğayı gösterecek biçimde, bir bütün halinde verilmiştir. Kent, sağ tarafta şehre doğru ilerleyen bir grup insan ve arka tarafta dağların yer aldığı, yer yer zeytin ağaçlarının olduğu 1ssız bir kare olarak yansıtılmıştır. Resmin arka düzleminde, dağın üzerine konumlanmış yerleşim fark edilmektedir. Sanatçı kompozisyonunu, kentin yaşamından çok vadi ve dağlarla çevrili halini yakalama üzerine kurmayı tercih etmiştir. Resim her ne kadar gerçekçi bir özellik gösterse de, genel havanın bıraktığı etki onu romantik bir anlayışa da yakınlaştırır.

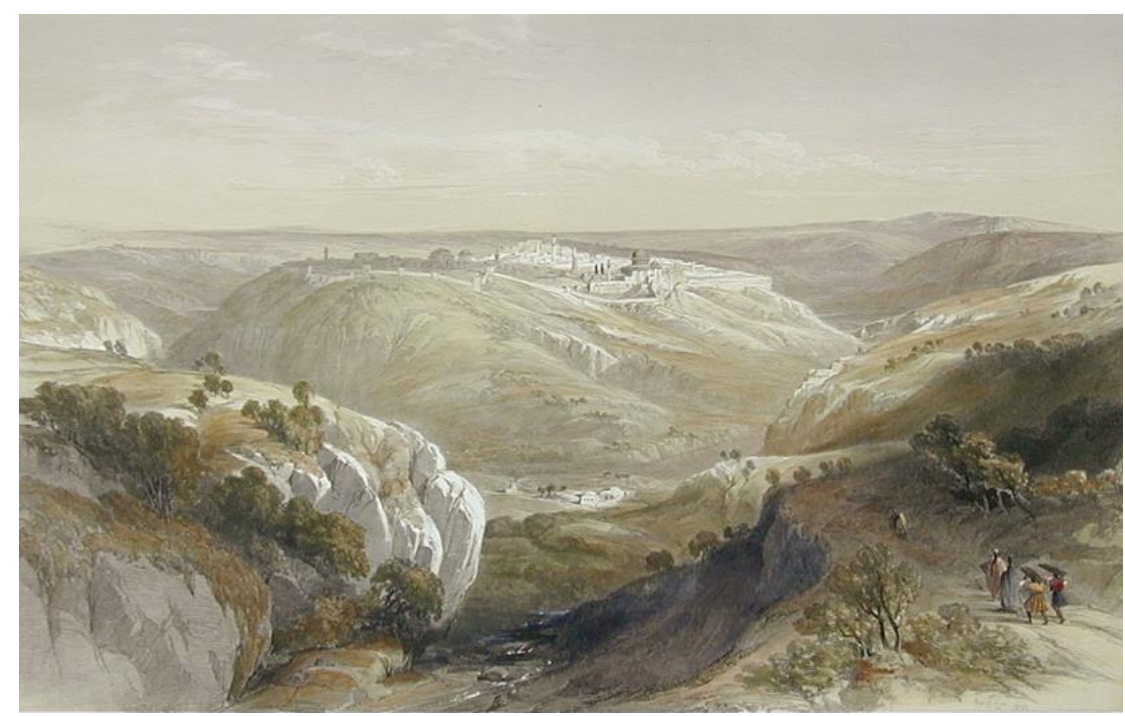

Foto 1. David Roberts, Kudüs'ün Güneyden Görünüşü (http://www.medinaarts.com/HF055.htmlErişim Tarihi: 15.02.2018)

Kenti çevreleyen dağ ve vadilerde, Batılılar için güçlü bir gizem vardır. Bu gizem, atmosferin dinginliğinde ve dağın üzerine konumlanmış olan Kudüs ile daha güçlenmiştir. William Henry Barlett'e ait olan Modern Kudüs adlı çalışmada, korunaklı surların gerisinde bir bütün olarak verilmeye çalışılan kent, çevresinde yer alan dağ ve vadilerle seyircisine sunulmaktadır (Foto 2). 
$\mathrm{Bu}$ topografik tablonun ön kısmındaki Doğulu insan topluluğu ile Oryantalist bir atmosfer yaratılmaya çalışılmıştır.

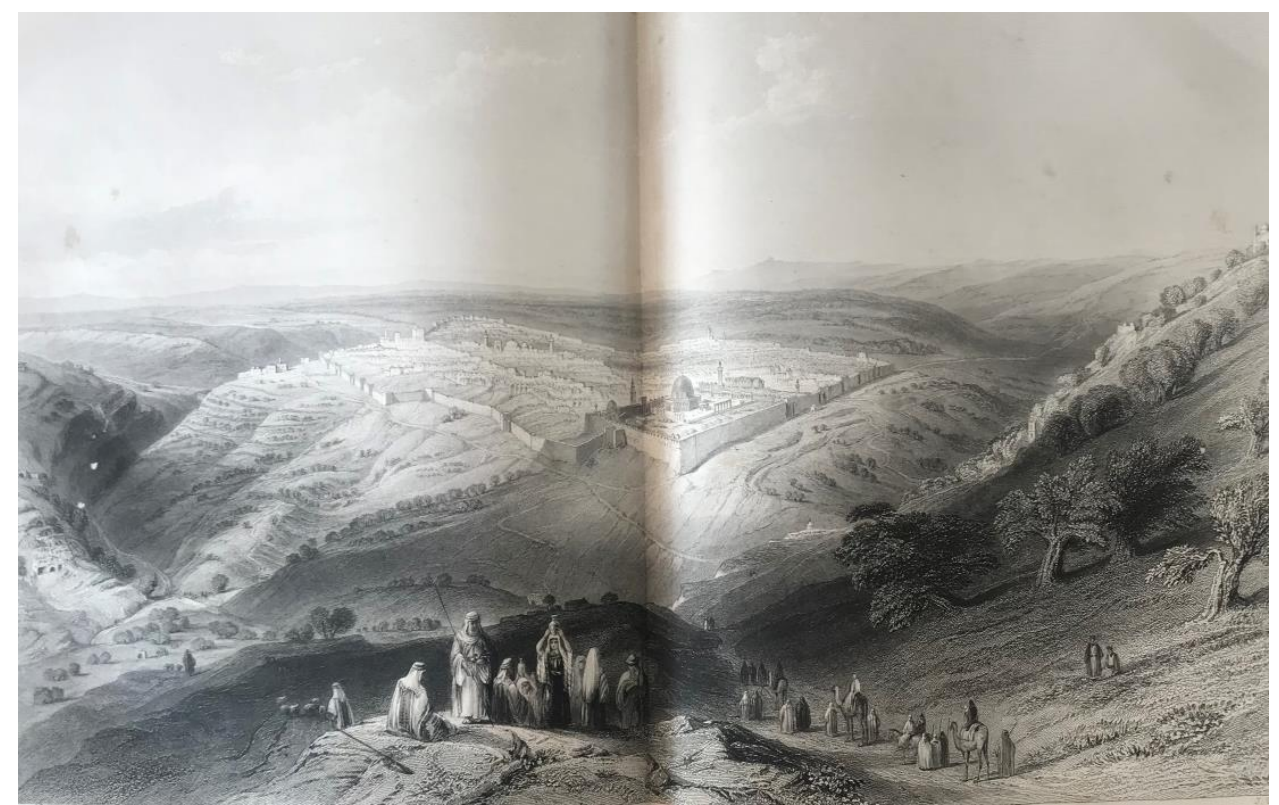

Foto 2. William Henry Barlett, Modern Kudüs, (Stebbing, 1847: 126)

Kudüs'e uğrayan gezginlerin kent ile ilgili gözlemlerinin ana temasını, Eski (Antik) Kudüs olarak bilinen bölüm oluşturmaktadır. Kudüs'ü konu alan gravürlerin çoğunluğunu, eski kent merkezi ile çevresinde bulunan dini yerleşimlerin de yansıtıldığı panoramik görüntüler oluşturmaktadır. Bu görüntülerde çoğunlukla belli bir yükseklik veya uzaklıktan kentin bütünü verilecek şekilde çalışılmıştır. Hazırlanan gravürlerden, gezginlerin kenti farklı bakış açılarından izlemekten büyük zevk aldıkları anlaşılmaktadır. Bu resimler çoğunlukla Zeytin Dağı, Scopus Dağ1 veya kente girişte kullanılan diğer yüksekliklerden bakılarak çizilmiştir. Bunlarda da kale surları içerisinde yer alan yerleşim alanı ve özellikle Mescid-i Aksa Camii ve Kubbet-üs Sahra gibi yapılar vurgulanmıştır.

Kentin panoramik olarak yansıtıldığı resimlerde, en fazla karşımıza çıkan yer hiç kuşkusuz Zeytin Dağı'dır'. Kudüs'ün doğusunda ve Kidron Vadisi'nin yanında yer alan Zeytin Dağı Musevilik, Hristiyanlık ve İslam dinlerinde önemli bir yerdir. Dağ, Hristiyanlar için Hz. İsa'nın hayatında; Kudüs'e giriş yaptığı (Matta 21: 1-11), çarmıha gerilmeden dua ettiği (Luka 22: 39-43) ve çarmıha gerilmek için yakalandığı yer olarak (Cömert, 1999: 131-132) önemli olaylarla

\footnotetext{
${ }^{1}$ Kudüs'ün doğusunda yer alan Zeytin Dağı, Musevilik, Hristiyanlık ve İslam dinlerinde önemli bir yerdir. Yahudi dini metinlerinde Kıyamet Günü'nde Yahudi milletinin kurtarıcısı Mesih'in, Zeytin Dağı üzerinden Kudüs'e geleceği aktarılır. Dirilişin gerçekleştiği, hesabın görülüp hükmün verileceği yer Yehoşafat Deresi'dir. Yani Zeytin Dağı'nın eteklerindeki Kidron Vadisi'dir. Bu nedenle, Yahudiler için Zeytin Dağı'nın yamaçlarındaki mezarlıklara gömülmek oldukça önemlidir. Bu nedenle en büyük Musevi Mezarlığı burada yer alır Ayrıca binlerce Hristiyan da ilk dirilenler arasına katılabilmek umuduyla veya inancıyla Zeytin Dăğ'nın eteklerinde beklemektedir (Çift- Harman, 2017: 58-59).
} 
irtibatlandırılır. Zeytin Dağı'nın dini açıdan taşıdığı anlam ve kentin en iyi panoramalarının alındığı bölge olması, buranın gravürlerde en fazla kullanıldığı yer olmasında başlıca etkenlerdir.

Kenti yüksek bir noktadan bakarak izlemekten zevk alan gezginlerin başında David Roberts gelmektedir. Sanatçının Zeytin Dă̆ı'ndan Kudüs adlı litografisinde, kentin doğu yönünden (Zeytin Dağı'ndan) bir görünümü yansıtılmıștır (Foto.3). Kidron Vadisi’nin üzerinde surlarla çevrili eski kentte, Haremi Şerif'in içinde, Mescid-i el Aksa Camii ve siluete egemen olan Kubbetüs Sahra yer almaktadır.

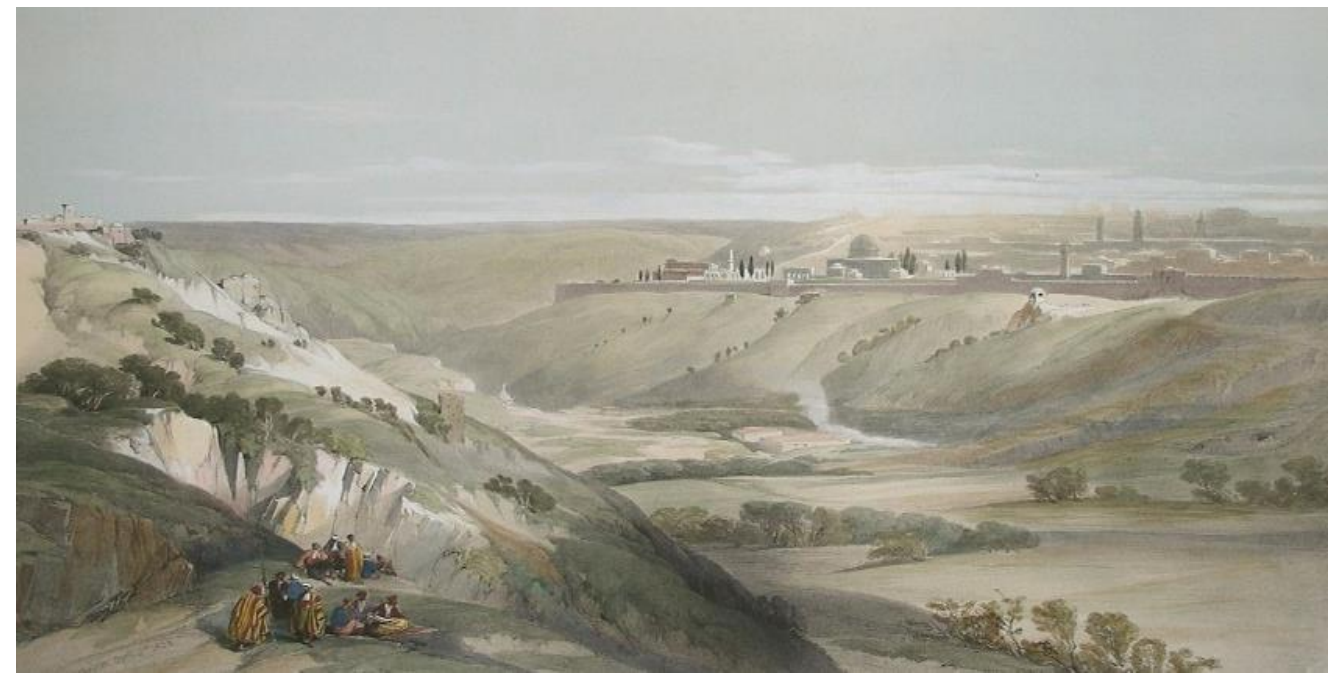

Foto. 3. David Roberts, Zeytin Dağından Kudüs, (http://www.medinaarts.com/HF054.htm Erişim Tarihi: 15.02.2018).

Zeytin Dă̆g'ndan Kidron Vadisi'nin gerisinde, kentin kubbeleriyle gösterilmesi anlayışının örneklerinden bir diğeri, Thomas Allom'a ait olan Zeytin Dă̆ı'ndan Kudüs'e Bakış isimli çalışmadır (Foto. 4). Gravürde, ön planda Doğulu giysilere bürünmüş iki erkek figürü ve bir keçi sürüsü yer almaktadır. Vadinin gerisinde kuzey doğudan görünen Kudüs, uzaktan ve siluet olarak çizilmiştir. Kent kubbe ve minareleri ile gösterilmiştir.

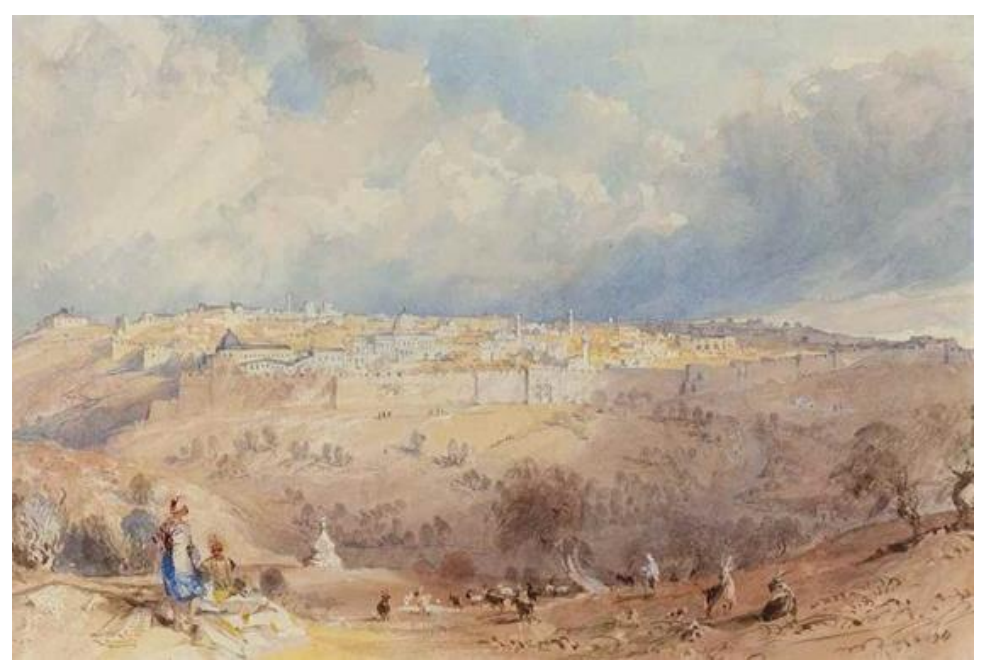

Foto. 4. Thomas Allom, Zeytin Dăğ'ndan Kudüs'e Bakış, (http://www.artnet.com/artists/thomasallom/jerusalem-from-the-mount-of-olives-by-the-tomb-of-IwkXRCd5haUcmLeL5cqIBg2 Erişim Tarihi: 20.08.2019) 
Kudüs'ün Zeytin Dağı'ndan bakılarak yansıtıldığı diğer bir örnek John Douglas Woodward'a aittir. Zeytin Dağı'ndan Kudüs adlı gravürde (Foto 5), ön planda yüksek dağlar ve vadiler arasında Doğulu giysiler içinde bir çiftçi aile yer almaktadır. Bunların gerisinde ise surlar içerisinde Eski Kudüs kenti görülmektedir. Kent kubbe ve minareleriyle verilmiştir.

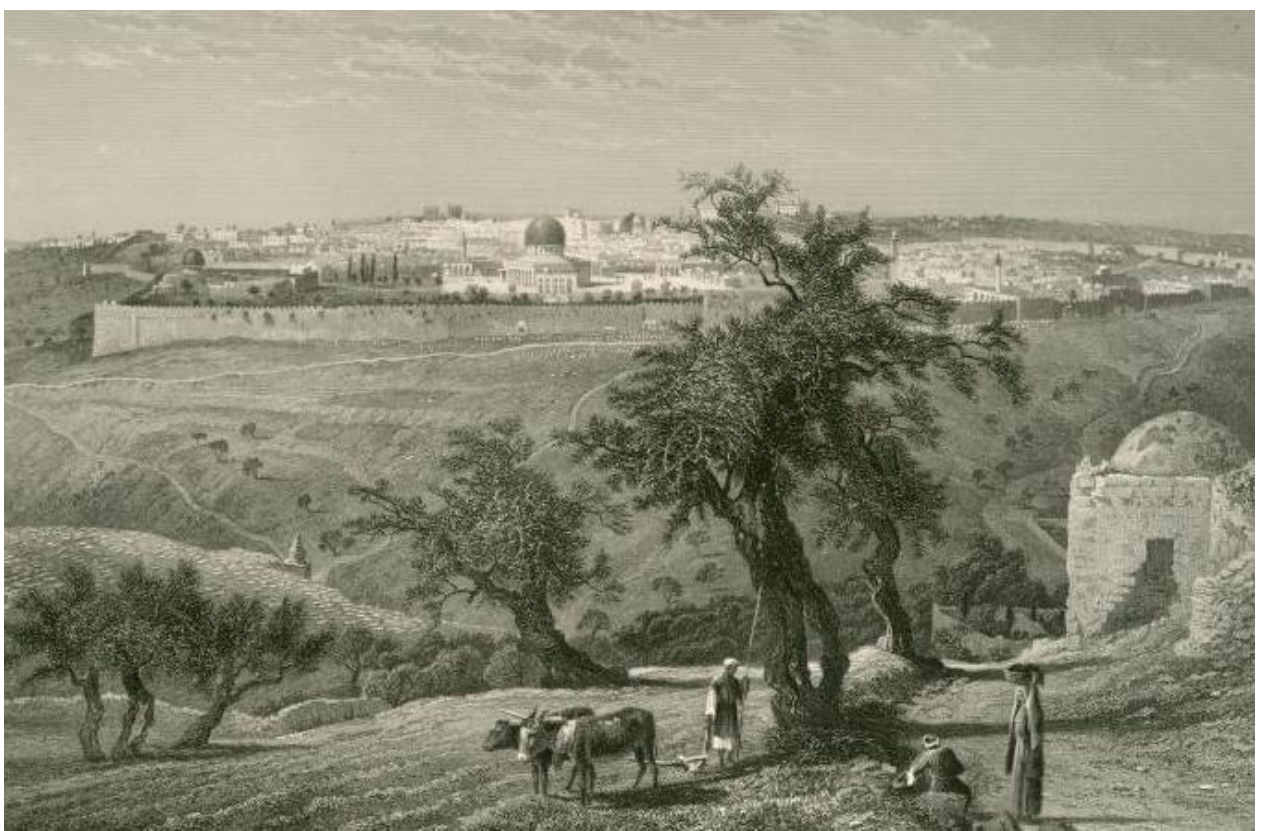

Foto. 5. John Douglas Woodward, Zeytin Dă̆ı'ndan Kudüs, (Wilson, 1881: 4).

Aynı anlayışta çalışılan gravürlerden bir diğeri de Barlett'e aittir. Sanatçı, Zeytin Dağı ve Kudüs isimli resimde, kenti, ön planda yer alan Doğulu figürlerin gerisinde bir siluet halinde vermiştir (Foto 6).

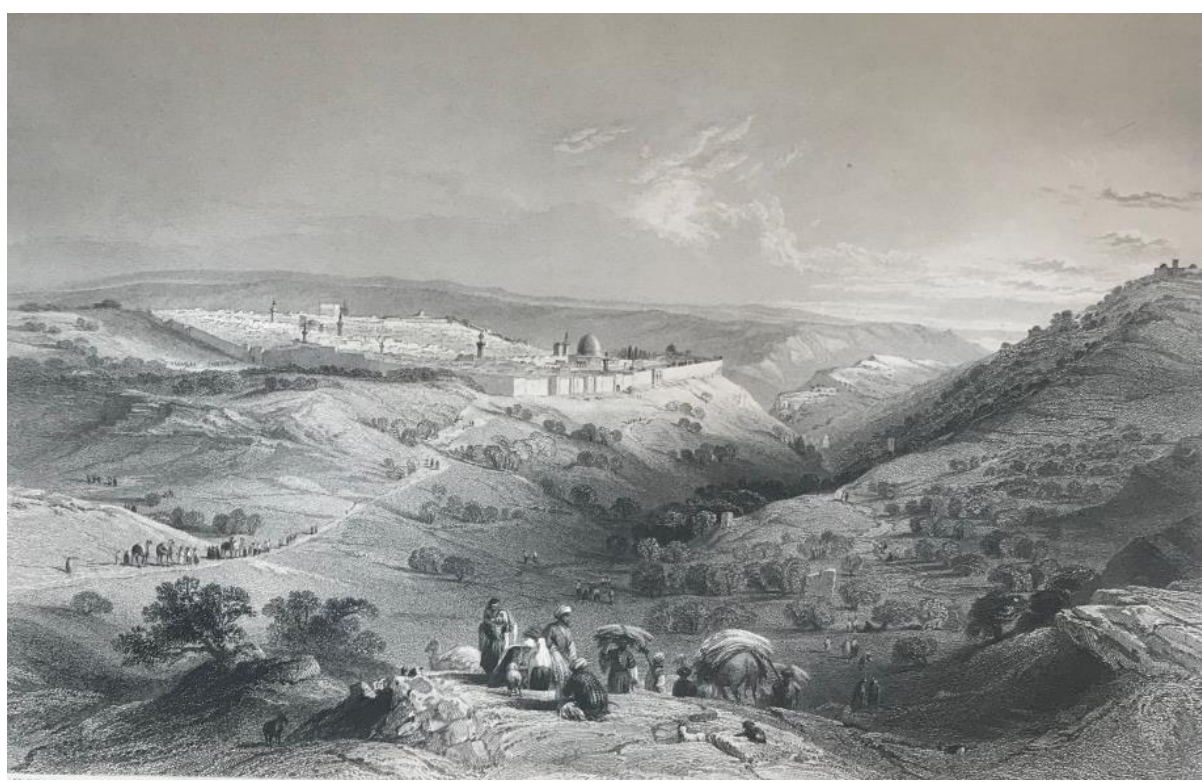

Foto 6. William Henry Barlett, Zeytin Dağı ve Kudüs (Stebbing, 1847: 146).

Turkish Studies - Social Sciences

Volume 14 Issue 6, 2019 
Kudüs'ü Zeytin Dă̆ı'ndan görüntüleyen diğer bir sanatçı Joseph Mallord William Turner'dir. Romantik bir anlayışla ele aldığı Zeytin Dă̆ı'ndan Küdüs adlı çalışmasında, ışık ve gölge oyunlarıyla açığa çıkarılan bir kent göze çarpmaktadır (Foto 7).

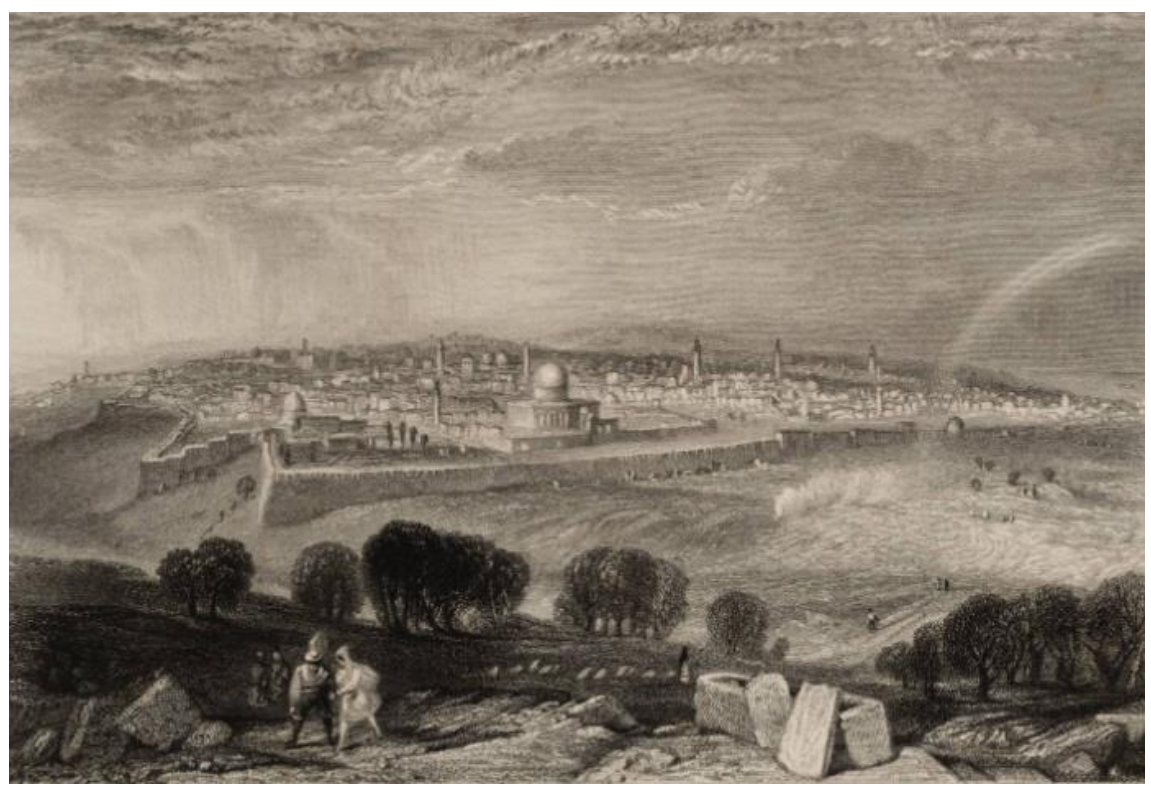

Foto 7. Joseph Mallord William Turner, Zeytin Dă̆ı'ndan Küdüs, (https://www.tate.org.uk/art/artworks/turner-jerusalem-from-the-mount-of-olivest05167 Erişim Tarihi: 07.09.2019)

Gravürde, Romantik etkinin yoğunluğu göze çarpsa da bütününde kenti panoramik olarak yansıtma kaygısının da güdüldüğ̈̈ görülmektedir. Ancak sanatçıya ait diğer bir çalışma olan Kudüs adlı gravürde farklı bir yaklaşım görülür (Foto 8). Kentin sur ve yapılarının yansıtılmasında belirgin bir abartı dikkati çekmektedir.

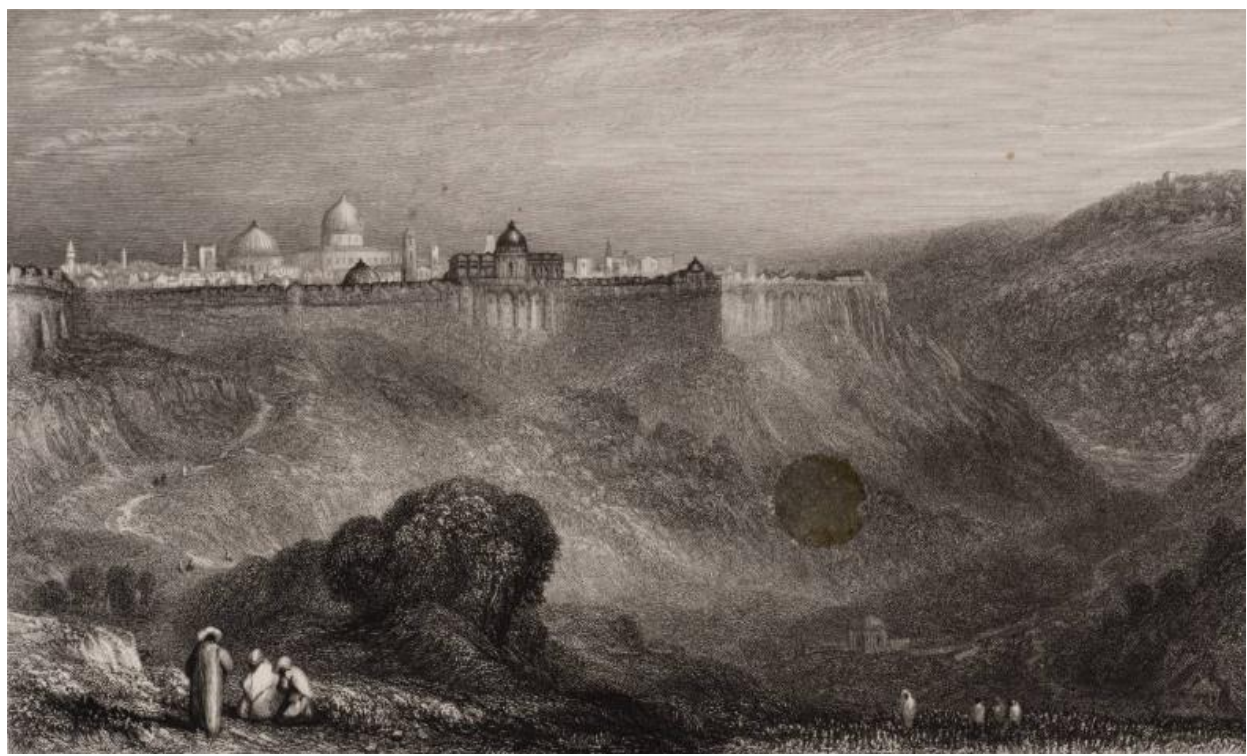

Foto. 8. Joseph Mallord William Turner, Kudüs, (https://www.tate.org.uk/art/artworks/turnerjerusalem-t04732 Erişim Tarihi: 07.09.2019)

\section{Turkish Studies - Social Sciences}

Volume 14 Issue 6, 2019 
Kudüs'de sanatçılar tarafindan ilgi gören noktalardan biri de Zeytin Dağı eteğinde yer alan Getsemani Bahçesi'dir. Hz. İsa Romalı askerlerce Getsemani Bahçesi'nde tutuklanmıştır. Bahçe şehir duvarlarının dışında, fakirlerin, hastaların ve Roma tarafından istenmeyen kişilerin sığındığı alandır. Bahçedeki zeytin ağaçlarının Hz. İsa döneminden kaldığına inanılmaktadır. (Çift-Harman, 2017: 109). Barlett'e ait Getsemani Bahçesi adlı çalışmada da bahçede bulunan zeytin ağaçları romantik bir ay ışığında resmedilmiştir (Foto. 9).

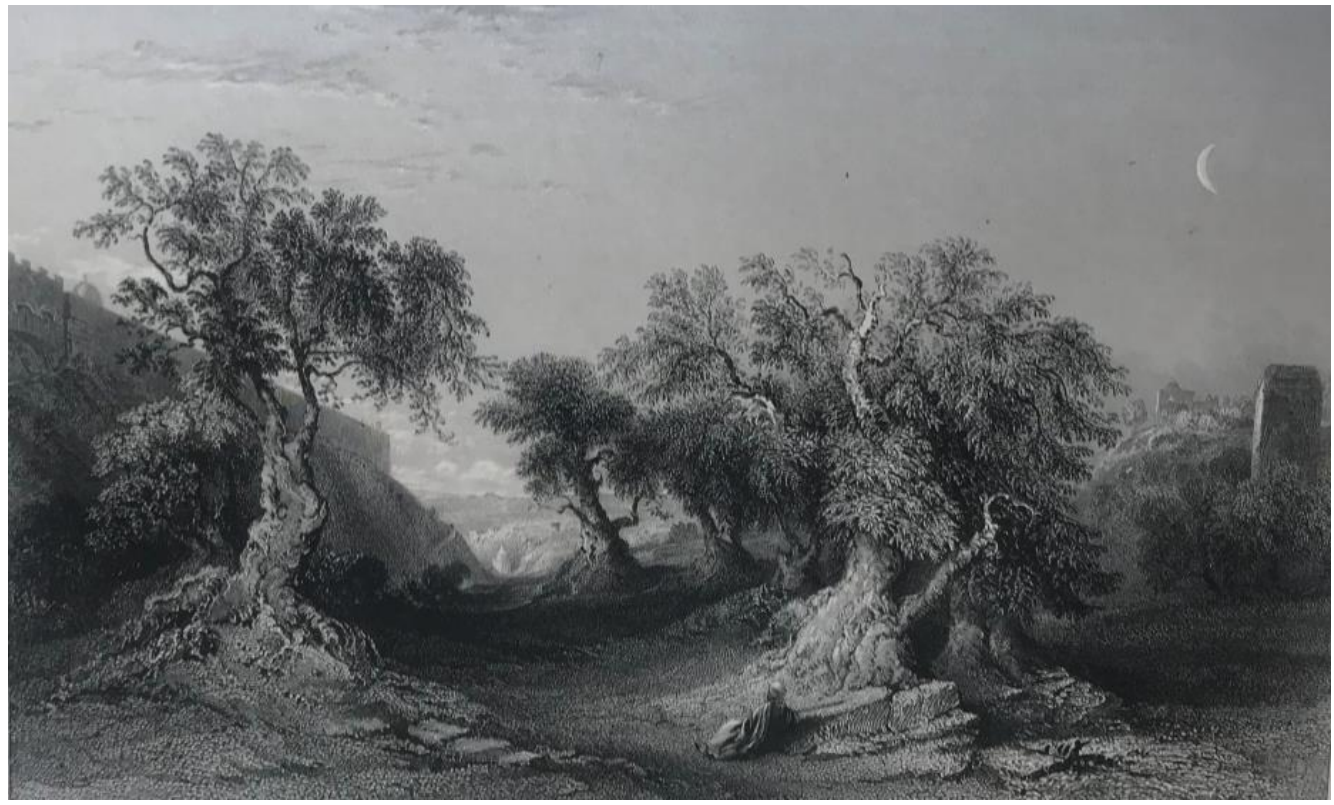

Foto 9. William Henry Barlett, Getsemani Bahçesi (Stebbing,1847:144)

Kudüs ile ilgili çalışmalar arasında, kentin panoramik görüntülerinin yanında, antik kentin içinden yapılan gravürler de mevcuttur. Bu gravürlerde en fazla ilgiliyi Harem-i Şerif alanı görmüştür. Barlett imzalı Haram 'ın Çevresi adlı resimde Mescid-i Aksa Camii ile Kubbet-üs Sahra tüm görkemiyle ve günlük yaşamın içinde verilmeye çalışılmıştır (Foto 10).

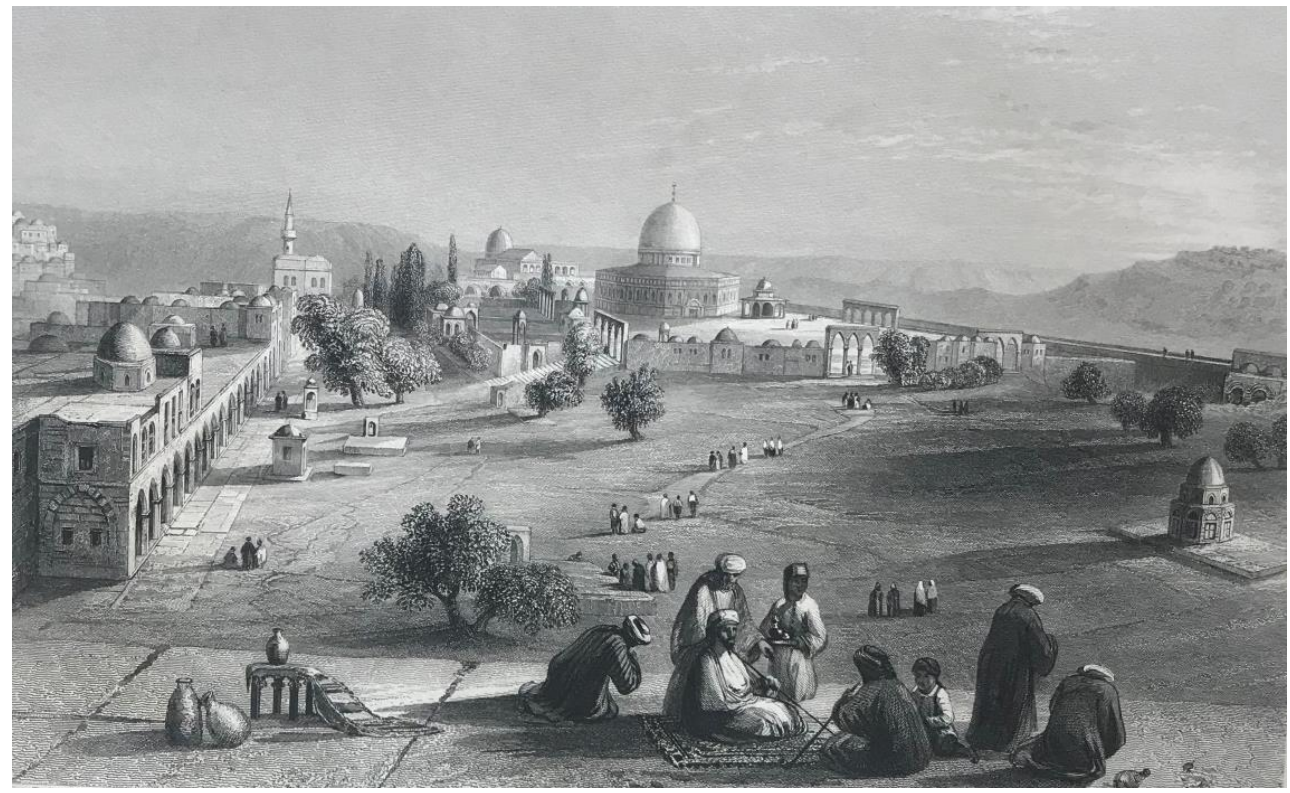

Foto 10. William Henry Barlett, Haram 'in Çevresi (Stebbing, 1847: 154)

Turkish Studies - Social Sciences

Volume 14 Issue 6, 2019 
Kudüs'ten gerçekleştirilen gravürler arasında kentin önemli mimari yapılarının konu edildiği gravürler de hayli yer tutmaktadır. Bu gruptaki eserlerin büyük bölümünde dini yapılar işlenmiş olup en sık vurgulananlar; Harem-i Şerif'te bulunan Kubbet-üs Sahra ve Mescid-i Aksa Cami'dir. İslam dinince kutsal sayılan mekânların başında gelen Haremi Şerif'in merkezinde yükselen ve Hz. Muhammed'in Mi'raca çıktığı makam olduğuna inanılan Kubbet-üs Sahra ${ }^{2}$, panoramik görüntülerde sürekli olarak vurgulandığı gibi ayrıntılı çalışmalarda da dikkat çekmektedir. Öyle ki bu bölgeyi konu eden seyahatnamelerin kapak sayfalarını dahi süslemektedir. 1881 tarihli C.W. Wilson'a ait Picturesque Palestine, Sinai and Egypt adlı eserin kapak sayfasında, Woodward tarafindan yapılmış olan Kubbet-üs Sahra'nın Güneyden Görünümü adlı gravürü yer almaktadir (Foto 11).

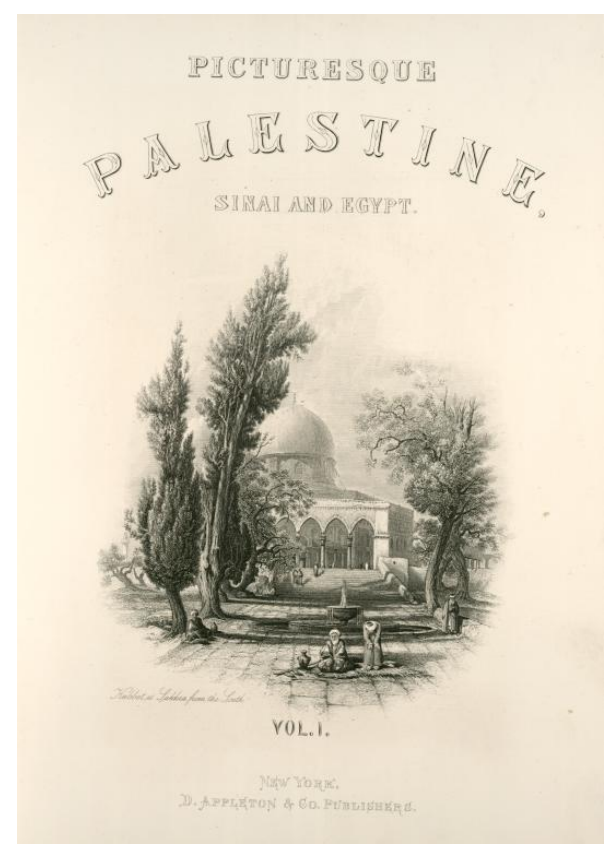

Foto 11. John Douglas Woodward, Kubbet-üs Sahra 'nın Güneyden Görünüşü, (Wilson, 1881)

Woodward'ın diğer bir gravüründe de yine Kubbet-üs Sahra konu edilmiştir. Kaya Kubbesi Platformu adlı çalışmada sanatçı, yapının platformuna çıkışı sağlayan kuzey köşesindeki kemerli girişi resmetmiştir (Foto 12). Gravürün ön planında ibadet eden Doğulu figürler yer almaktadır. Mimari yapıdaki kubbe, kemer gibi öğeler büyük bir gözlem gücü ile yansıtılmış, süslemeler ayrıntıcı bir gözle aktarılmıştır.

\footnotetext{
${ }^{2}$ Kubbet-üs Sahra mescidi kutsal Harem-i Şerif'in bir parçası olarak Kadim Kudüs'ün Müslüman Mahallesi'nde yer almaktadır (Filistin Rehberi, t.y.: 5). Emevi halifesi Abdülmelik ibn Mervan tarafından 691 yllında inşa edilmiş olup Erken İslam mimarlığının en görkemli yapılarındandır. Kutsal kayayı (Muallak Taşı) kuşatan dairesel planlı bir kubbe ile örtülü yapı, sekizgen bir plana sahiptir (Tahman, Üç Kitaplı Kentler, 19. Yüzyıl Fotoğraflarında Kudüs ve Kutsal Topraklar https://artsandculture.google.com/exhibit/ARTP3HZa?hl=tr Erişim Tarihi: 15.02.2018).
}

\section{Turkish Studies - Social Sciences}




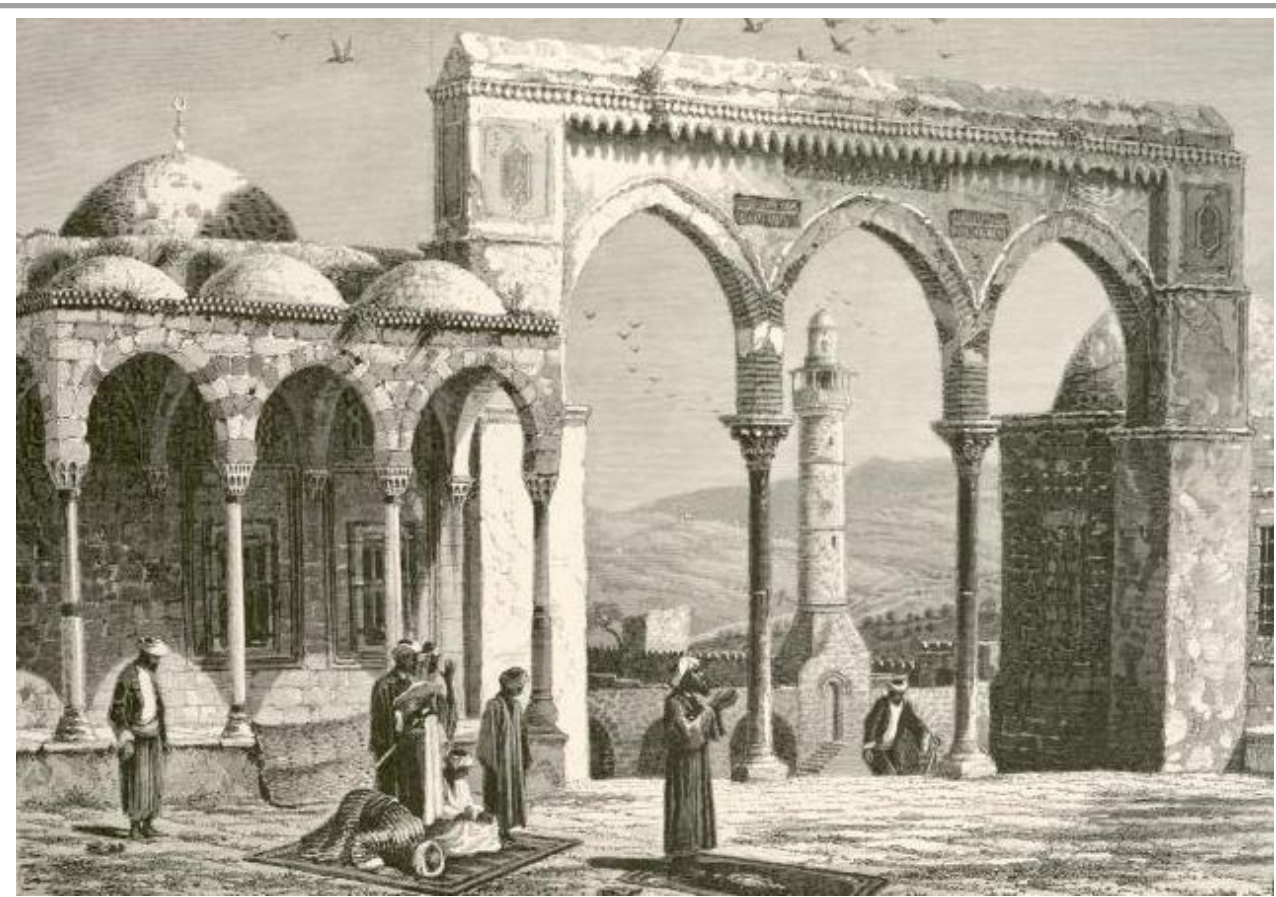

Foto 12. John Douglas Woodward, Kaya Kubbesi Platformu (Wilson, 1881: 63)

Gravürlerde yer alan diğer bir yapı İslâm kültürünün simgesi olan Mescid-i Aksa Camii'dir ${ }^{3}$. Haremi Şerif'te bulunan cami Woodward'a ait El Aksa Camii- Kudüs adlı ağaç baskıda işlenmiştir. Ayrıntıcı bir anlayışla ele alınan örnekte, yapı Kudüs'ün simgelerinden olan zeytin ağacının gerisinde yer almaktadır. Ağacın gölgesinde duran iki figür ile bunların hemen yanında ibadet eden diğer iki figürün gerisinde ise beş gözlü son cemaat yerinin bulunduğu giriş cephesi resmedilmiştir (Foto 13).

\footnotetext{
${ }^{3}$ Müslümanların ilk kıblesi, en kutsal sayılan üç mescidden biri olan Mescid-i Aksa, Harem Şerif adıyla da bilinir ve çevresinde bulunan Kubbet-üs Sahra mescidini de ihtiva eder. Kuran-1 Kerim'de Mescid-i Aksa, bir bina değil kutsal bir toprak parçasıdır. Sonraları Emeviler bu ismi kullanarak yapılarını adlandırmışlardır (Uğurluel, 2017: 196-197). Gravürde geçen Mescid-i Aksa Ulu Camii, Kudüs’ün İslam orduları tarafından fethedilmesine (637) müteakip Hz. Ömer tarafından inşa ettirilmiştir. Mescid-i Aksa, kıble eksenine paralel sahınlardan oluşan bugünkü şeklini Eyyubiler (11871250) döneminde almış, Memluk (1250-1517) ve Osmanlılar (1517- 1917) döneminde onarımlardan geçmiştir (Tahman "Üç Kitaplı Kentler, 19. Yüzyıl Fotoğraflarında Kudüs ve Kutsal Topraklar" https://artsandculture.google.com/exhibit/ARTP3HZa?hl=tr Erişim Tarihi: 15.02.2018).
}

\section{Turkish Studies - Social Sciences}

Volume 14 Issue 6, 2019 


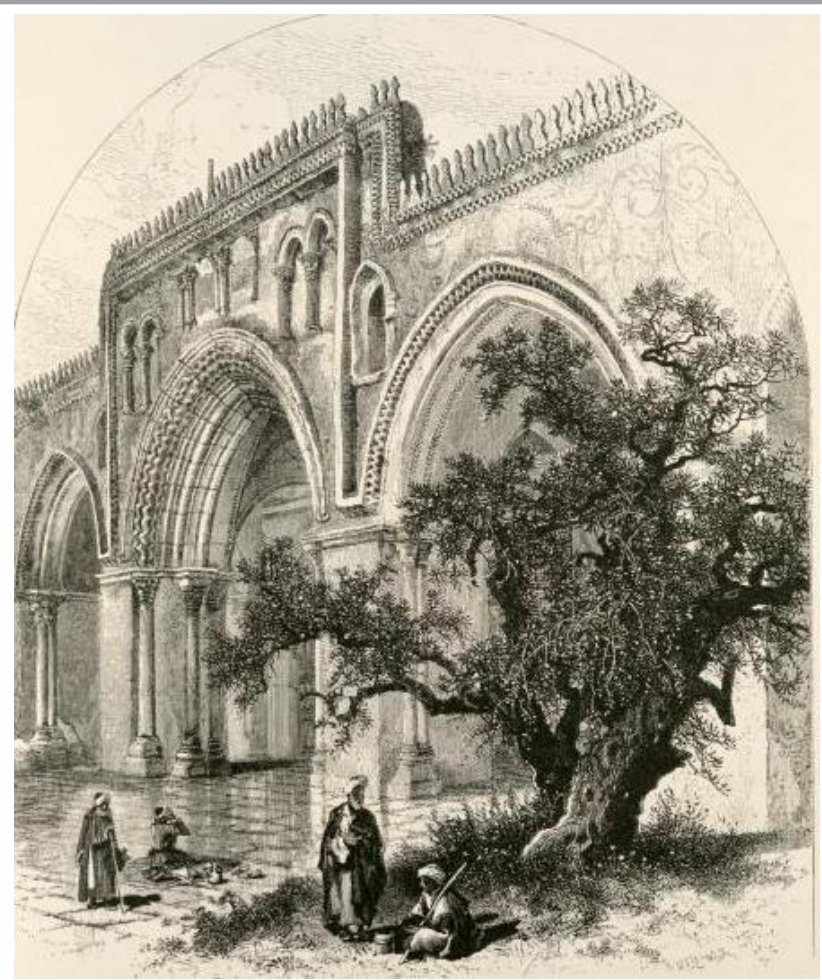

Foto 13. J. D. Woodward, El Aksa Camii- Kudüs, (https://digitalcollections.nypl.org/items/510d47d9-5dbd-a3d9-e040-e00a18064a99 Erişim Tarihi: 15.02.2018)

Gravürlerde üzerine durulan diğer bir yapı grubu kiliselerdir. Özellikle Kutsal Kabir veya Yeniden Doğuş Kilisesi olarak da bilinen ve Hz. İsa'nın çarmı gerildiği, göğe yükseldiği, kabrinin olduğu ve tekrar dirileceği yer olarak bilinen Kamame Kilisesi ${ }^{4}$, en yoğun ilgi gören örnektir. Gravürlerde sıklıkla yer verilen yapıya gezginlerin kitap kapaklarında da rastlanılmaktadır. Gezgin sanatçı Robert'a ait olan Kutsal Kabir Kilisesi'ne Giriş adlı litografi buna güzel bir örnektir (Foto 14).

\footnotetext{
${ }^{4}$ Eski Kudüs'ün Hristiyan Mahallesi'nde bulunan ve Doğu Hristiyanlarınca Diriliş Kilisesi, Araplarca Keniset'ül- Kıyame ve yabancı kaynaklarda da The Holy Sepulchre olarak adlandırılan Kilise, Hristiyan inanıșına göre İsa Mesih'in kabir (Kutsal Kabir) ve diriliş yeridir (Çift- Harman, 2017: 119; Satış -Ceyhan, 2012: 26). Kilise, Doğu Roma İmparatoru Büyük Constantinus'un annesi Helena tarafından Hz.İsa'nın kabri olduğu iddia edilen yer üzerinde inşa edilmiştir. Hristiyanların hac mahalli olan bu kilise, bütün Hristiyan cemaatleri tarafindan kutsal kabul edilmektedir. (Kılıç- Satış, 2011: 225-226).
}

\section{Turkish Studies - Social Sciences}




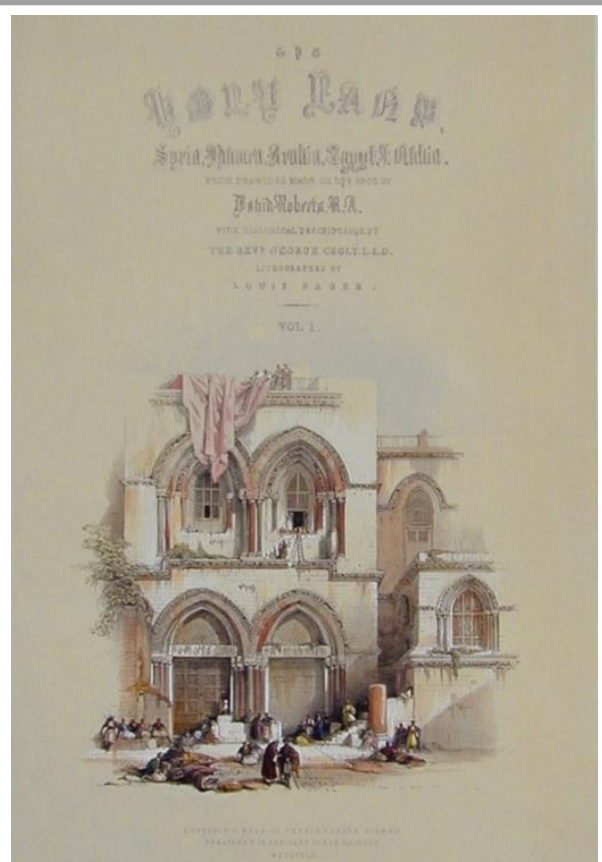

Foto. 14. David Roberts, Kutsal Kabir Kilisesi'ne Girişs (http://www.medinaarts.com/HF059.htm Erişim Tarihi: 15.02.2018)

Kilisenin konu edildiği diğer bir gravür Barlett'e aittir. Kutsal Kabir Kilisesi adlı gravürde yapı, önünde yer alan kalabalık insan figürleri ile beraber verilmiştir (Foto 15).

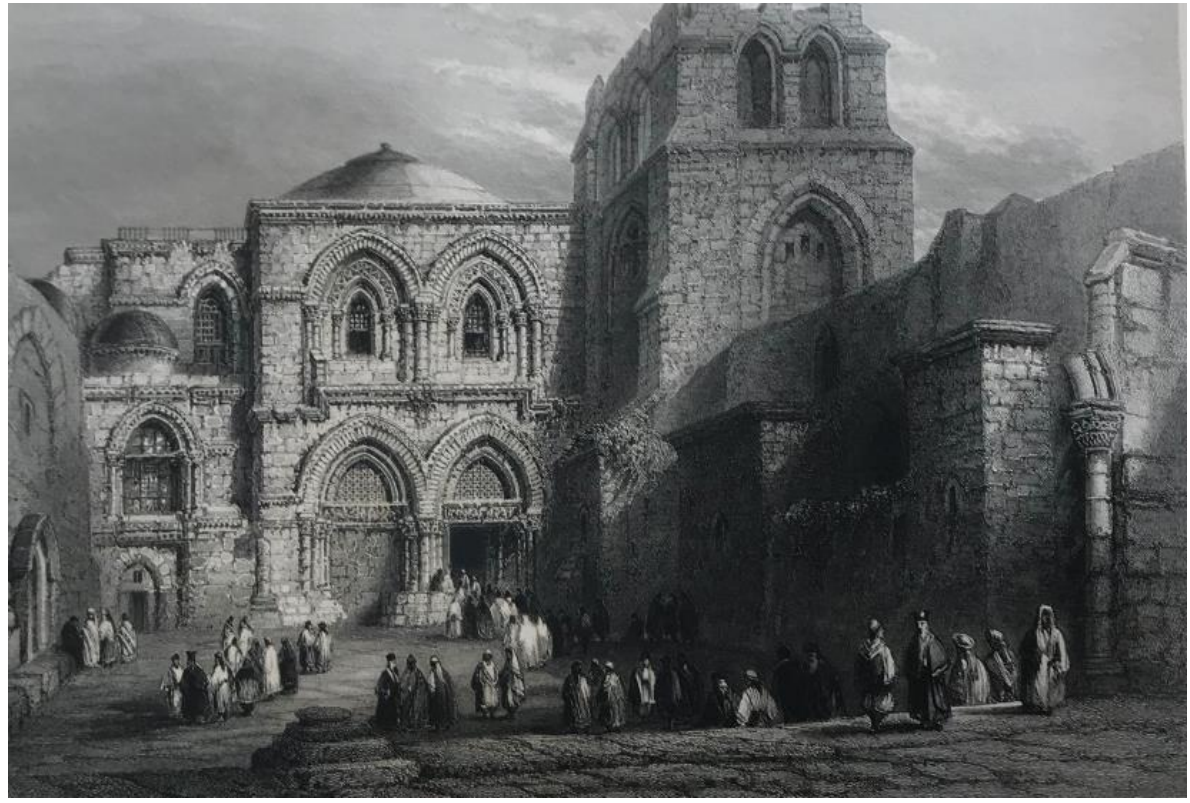

Foto. 15. William Henry Barlett, Kutsal Kabir Kilisesi (Stebbing,1847:131).

Turkish Studies - Social Sciences

Volume 14 Issue 6, 2019 
Diğer bir çalışma, Woodward'a ait Kutsal Kabir Kilisesi'ne Giriş adlı ağaç baskıdır (Foto. 16). Gravürde, yapının giriş cephesi resimlenmiştir. Avlusunda Hristiyan hacıların teşbih ve emanetleri satın aldıkları yapı iki katlı, kemerli girişli ve kubbeli olarak yansıtılmıştır.

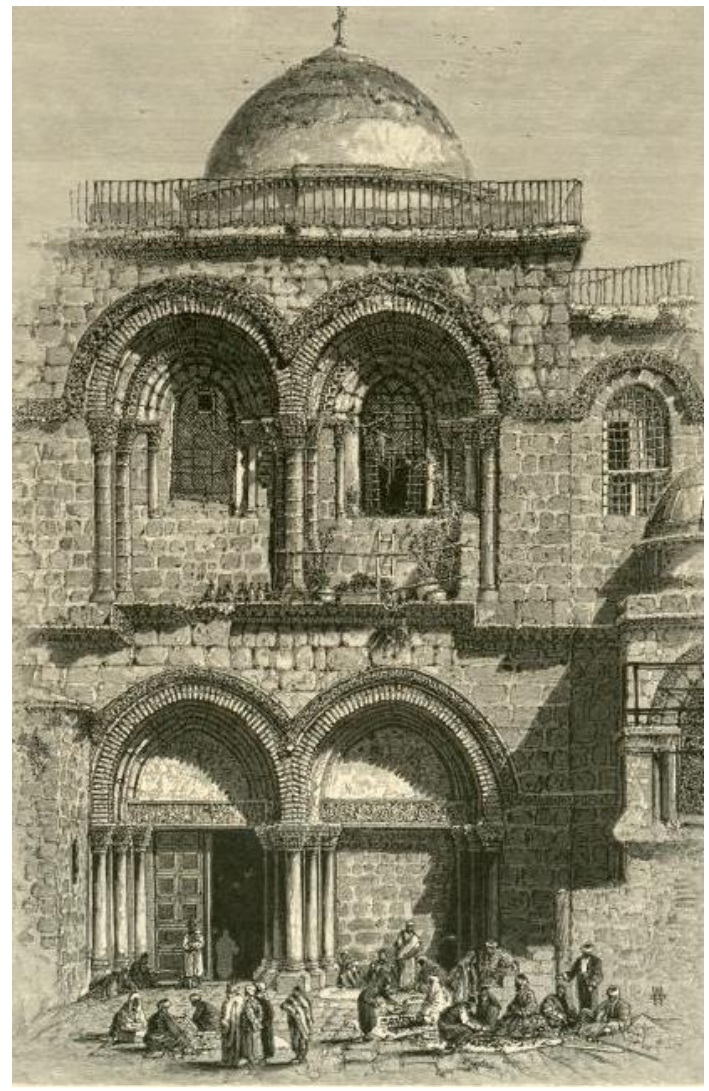

Foto. 16. John Douglas Woodward, Kutsal Kabir Kilisesi’ne Giriş (Wilson, 1881:16)

Kilise, Hristiyanlık açısından son derece önemli olan ve her yıl kutlanan Paskalya Bayramı'na da ev sahipliği yapmaktadır. İsa Peygamber'in çarmıha gerilip tekrar dirildiğine inanılan gün her yıl Paskalya Bayramı olarak kutlanmakta ve bu bayram öncesi Kamame Kilisesi'nde meşhur Kutsal Ateş Ayini düzenlenmektedir (Akyol, 2019: 7). Söz konusu ayin kilisenin içinde The Holy Sepulchre ya da Kutsal Mezar denilen ve Hristiyan inancında Hz. İsa'nın mezarı kabul edilen yerde (Satış -Ceyhan, 2012: 26) yapılmaktadır. Bu sahne, Woodward'a ait olan Kutsal Kabir Tapınağ $\breve{l}$ adlı ağaç baskıda görülmektedir (Foto. 17). Kilisenin iç kısmının görüldüğü ağaç baskının açıklama kısmında; büyük boyutlu şamdanların sadece kutsal günlerde kullanıldığı belirtilmektedir. Gravürde bu an resmedilmiştir. Resimde, yanan büyük şamdanların gerisinde, Hz. İsa'nın mezarının kapısının iki kenarında iki din adamı yer almaktadır. 


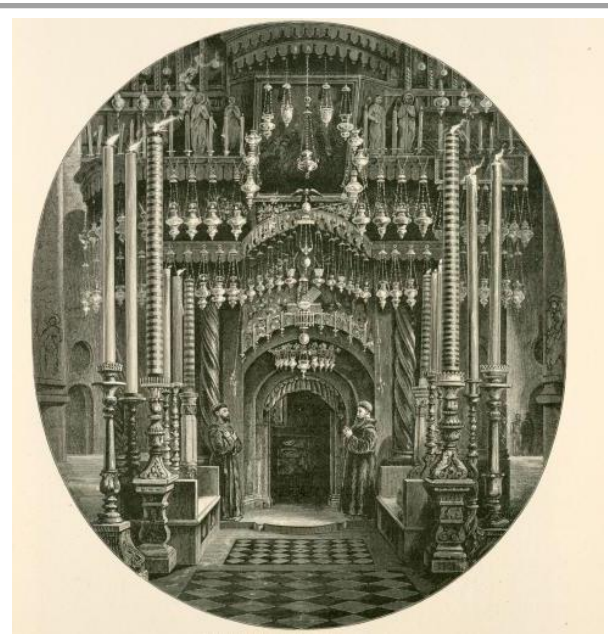

Foto 17. John Douglas Woodward, Kutsal Kabir Tapınağı (Wilson, 1881: 17)

İngiliz gezginlerin Hz. İsa'nın hayatıyla ilgili üzerinde durdukları diğer bir mekân, Via Dolorosa olarak bilinen Hz. İsa'nın çile yoludur ${ }^{5}$. Harry Fenn tarafından yapılmış olan ağaç baskıda, bu yol üzerinde, ikinci ve üçüncü durak arasında yer alan "Ecce Homo" kemeri resmedilmiştir (Foto. 18). Kemer, İmparator Hadrian zamanından kalma kapının bir parçasıdır ve dönemin Romalı valisi Pilatus bu kemerin üzerine çıkarak halka seslenmiş;; "Ecce Homo" "işte o insan" demiştir (Cömert, 1999:134). Gravürde, cadde üzerinde elinde asasılyla yolculuğuna devam eden bir Hristiyan hac1 Ecce Homo kemerinin hemen önünde verilmiştir.

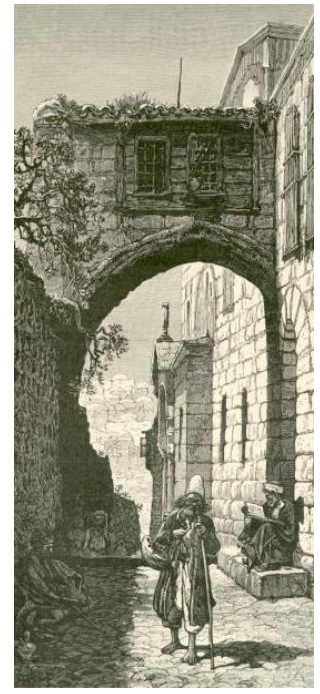

Foto. 18. Harry Fenn, Via Dolorosa- The Ecce Homo Kemeri (Wilson, 1881: 24)

\footnotetext{
${ }^{5}$ Via Dolorosa, Hz. İsa'nın yargılanıp cezalandırıldığı, daha sonra üzerinde çarmıha gerileceği haç kendisine taşıttırılarak 1stırap içinde Golgota Tepesine kadar yürütüldüğü ve bu sırada birtakım acı olayların yaşandığı yoldur. Bu olaylar anısına duraklar oluşturulmuş ve kiliseler inşa edilmiştir. 14 duraktan oluşan bu yol Hristiyanlar için çok önemli olup, yolu tamamlayanlar hacı olmaktadır.
} 
Gravürlere konu olan diğer bir dini mekân, Kidron Vadisi'nde bulunan Meryem Ana Türbesi' dir ${ }^{6}$. Barlett imzalı Meryem 'in Türbesi, Kudüs adlı gravürde sivri kemerli giriş cephesi resmedilmiştir (Foto. 19)

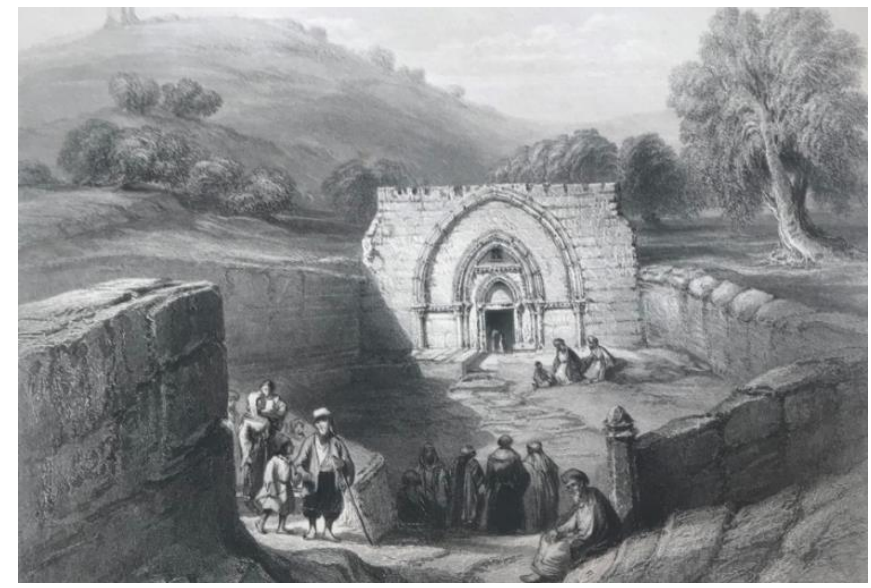

Foto. 19. William Henry Barlett, Meryem 'in Türbesi, Kudüs, (Stebbing, 1847: 145)

Dini yapılar arasında Davud Peygamber ve oğlu olan Absalom'un Türbesi gibi binalar da resimlenmiştir. Yahudi inancında önemli yeri olan bu yapılar arasında en büyük ilgiyi ise elbette Batı Duvarı olarak da bilinen Ağlama Duvarı ${ }^{7}$ görmüștür. Barlett'e ait Yahudiler'in Ağlama Yeri, Kudüs adlı gravürde erkek ve kadınlardan oluşan grup ibadet ederken resmedilmiştir (Foto. 20).

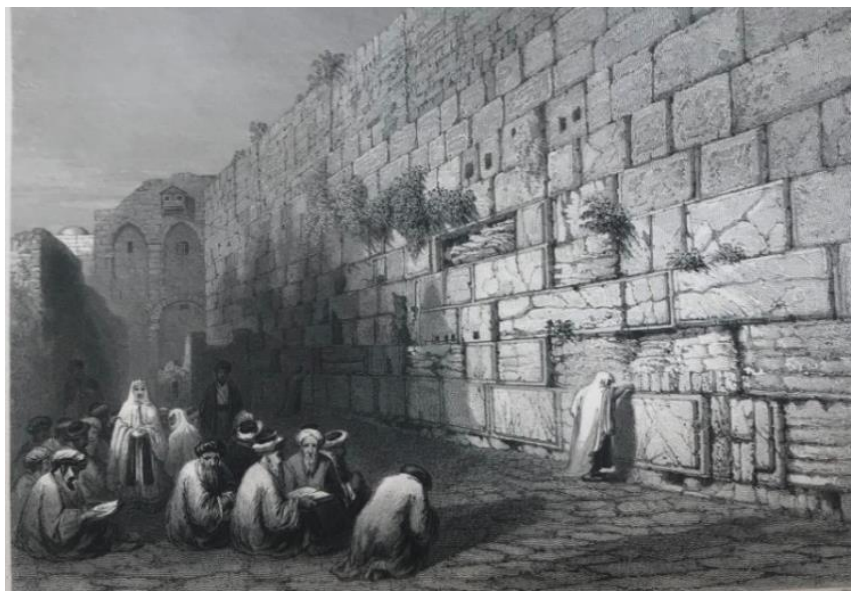

Foto. 20. William Henry Barlett, Yahudiler'in Ağlama Yeri, Kudüs (Stebbing, 1847: 145)

Kudüs'ü konu alan gravürlerde, yoğun şekilde üzerinde durulan diğer bir yapı grubu, kente girişi sağlayan kale kapılarıdır. Roberts,'e ait Şam (Damascus) Kapısı adlı litografide, kentin yedi

\footnotetext{
${ }^{6}$ Meryem Ana Türbesi, Hz.Meryem'in vefatından sonra bir süre gömülü kaldığı düşünülen mekândır (Çift- Harman, 2017:87).

${ }^{7}$ Batı Duvarı, yani günümüzde bilinen ismiyle Ağlama Duvarı, Yahudiler'in Kudüs’te ibadet edeckleri en kutsal alandır. Bu duvarın ait olduğu Süleyman Mâbedi’nin (Beit ha-Mikdaş) inşasına ilk defa Hz. Süleyman tarafindan, saltanatının dördüncü yılında başlanmış ve yedi yıl altı ayda (yaklaşık M.Ö. 967 veya 953) tamamlanmıştır. Bâbilliler'in Kudüs'ü işgali sırasında (M.Ö. 587 veya 586) yağmalanan ve yakılan mâbed, M.Ö. 537-515 yılları arasında Kral Hirodes (Hérode) tarafından yeniden yapılmıştır. Ancak yapı, M.S. 70 yılında Kudüs'ün Romalılar tarafindan kuşatılması sırasında tekrar yakılıp yıkılmıştır. Yahudiler bu duvarın önünde ibadet eder, çeşitli törenler gerçekleştirirler (https://islamansiklopedisi.org.tr/aglama-duvari, Erişim Tarihi: 07.09.2019).
}

\section{Turkish Studies - Social Sciences}


giriş kapısından en görkemlisi olan Şam Kapısı resmedilmiştir (Foto. 21). İki kuleli olan yapının ön kısmındaki kente giriş ve çıkış yapan kervanlar, resme oryantalist bir anlayış katmıştır.

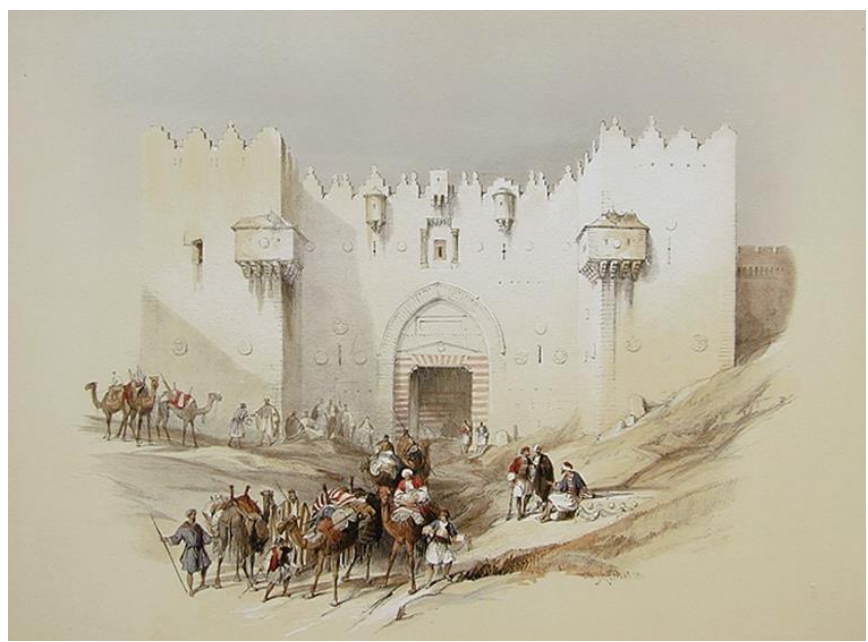

Foto. 21. David Roberts, Şam (Damascus) Kapısl, (http://www.medinaarts.com/HF060.htm Erişim Tarihi: 15.02.2018).

Diğer bir kapı olan El Halil (Yafa) Kapısı Barlett'in bir gravürüne konu olmuştur. Yafa Kapısından Giriş adlı resimde şehre giriş yapan bir kervana yer verilmiştir (Foto. 22)

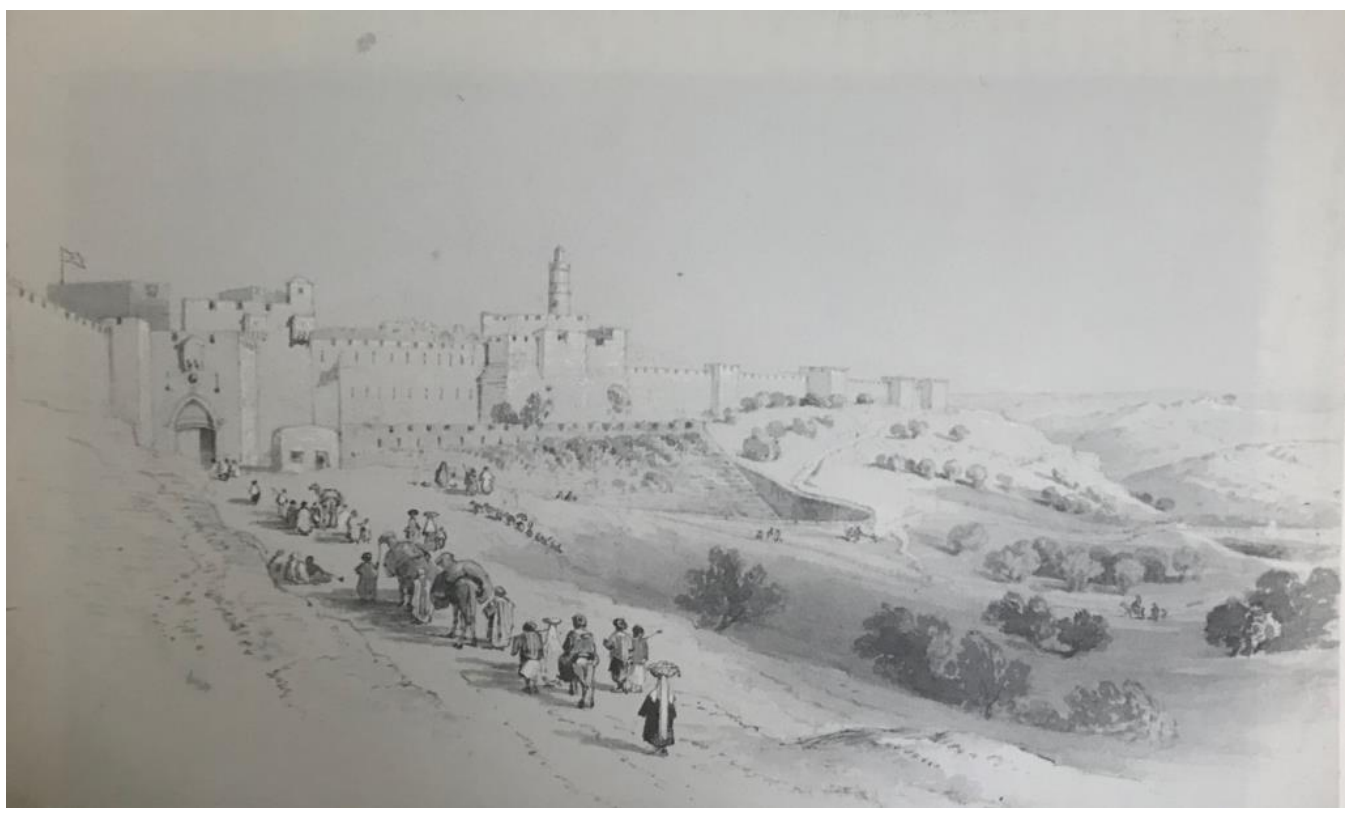

Foto. 22. William Henry Barlett, Yafa Kapısından Giriş, (Ross, 1973: Lev.19) 
Kudüs'e uğrayan gezginlerin üzerinde durdukları kapılardan bir diğeri de Altın Kapı olarak bilinen Tövbe ve Rahmet Kapısı'dır ${ }^{8}$. Barlett imzalı Altın Kapı, Kudüs adlı gravürde, ön kısımdaki Müslümanlara ait olan mezarlığın gerisinde Altın Kapı'ya yer verilmiş̦tir (Foto 23).

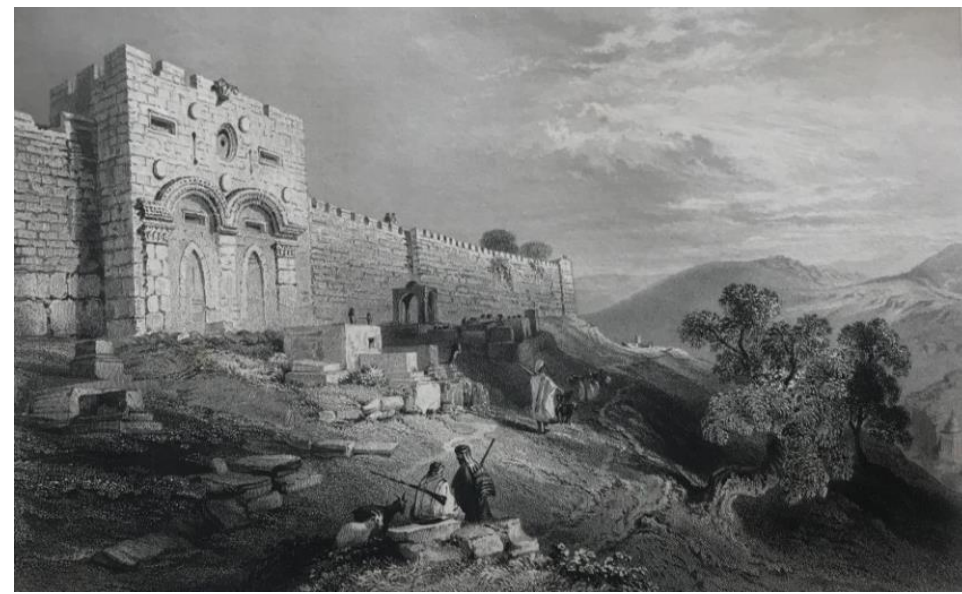

Foto. 23. William Henry Barlett, Altın Kapl, Kudüs (Stebbing, 1847: 159)

Gezgin sanatçıların kenti gezerken dikkatlerini çeken diğer bir yapı grubu su yapılarıdır. Çok sayıda gravürde yer verilen bu yapılar arasında en gösterişli olanlarından biri Kayıtbay Sebili olarak bilinen, Memluk Sultanı Kayıtbay'ın 1482 tarihli Kayıtbay Sebili'dir (Çift- Harman,2017: 200). Woodward'a ait Harem-i Şerif'in Batı Tarafi adlı ağaç baskısında görülen kare planlı yapı, soğan kubbesi ve süslemeleri ile Memluk sanatı izlerini taşımaktadır (Foto 24).

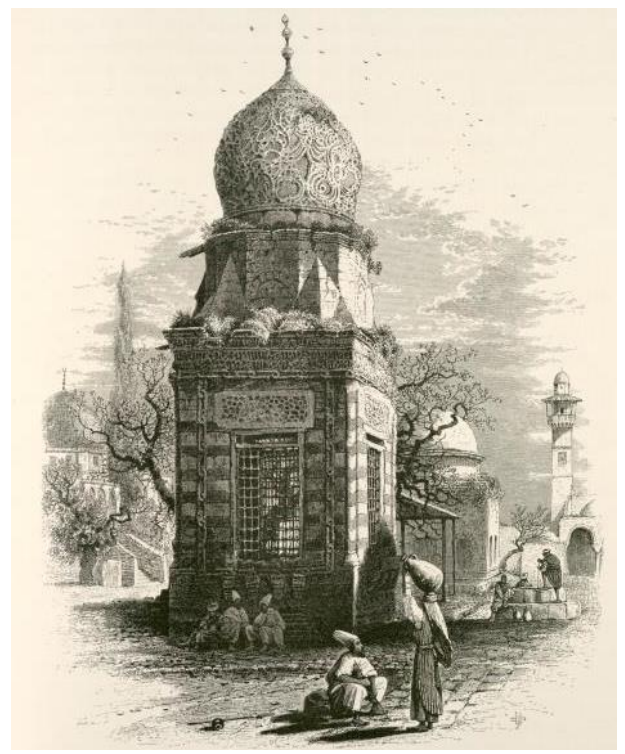

Foto. 24. John Douglas Woodward, Harem-i Şerif'in Batı Tarafi (Wilson, 1881: 53)

\footnotetext{
${ }^{8}$ Kapı, Yahudi ve Hristiyanlar arasında Altın Kapı olarak anılmakta ve ahir zamanda Mesih'in şehre bu kapıdan gireceğine inanılmaktadır. Kapı, Hz. Ömer zamanında kapatılmıştır. Ön kısmında Müslüman Mezarlığı yer almaktadır (Çift- Harman, 2017: 63, 188)
}

\section{Turkish Studies - Social Sciences}


Gravürlerde dikkatleri çeken diğer bir yapı Kanuni Sultan Süleyman döneminde Mescid-i Aksa su sebili projesine dahil edilen ve 1531-1542 yılları arasında hayata geçirilmiş sebillerden biri olan Babü's-Silsile Sebili (Babu'l-Mahkeme Sebili)'dir (Filistin Rehberi, t.y.: 11). Woodward'a ait gravürde ayrıntılı biçimde ele alınan yapının zengin süslemeleri büyük bir titizlikle yansitılmıştır (Foto. 25).

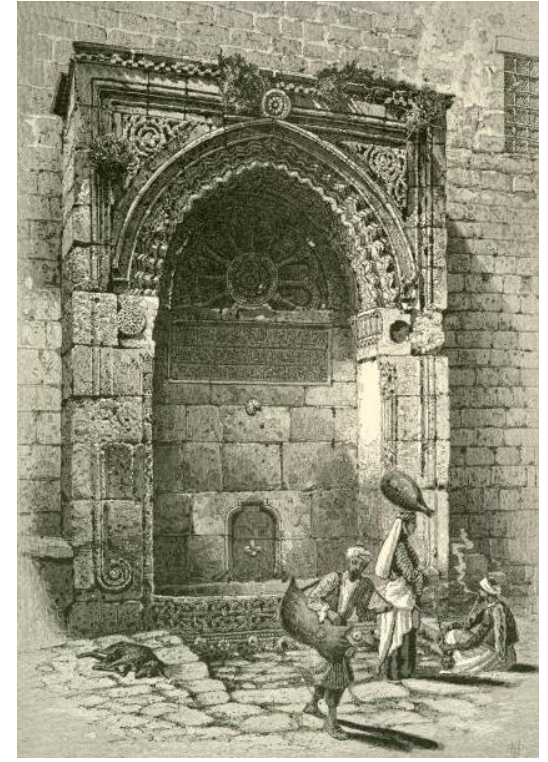

Foto. 25. John Douglas Woodward, Babü's-Silsile Sebili (Wilson, 1881: 48)

Kudüs toprakları üzerinde seyahat eden gezginlerin ev ve sokaklarla da ilgilendikleri görülmektedir. $\mathrm{Bu}$ ilgi, evlerin dış mimarisi ve sokak düzeni kadar, içlerindeki yaşama da gösterilmiştir. Barlett'e ait olan Kudüs'te Bir Hristiyan Ailenin Evinin İçi adlı gravürde, kemerli ve kubbeli geniş bir iç mekânda ev ahalisi resmedilmiştir (Foto 26). Şark ev kültürü; işlemeli sehpaları, yer minderleri ve dilimli kemerli pencereleriyle ayrıntılı bir biçimde verilmiştir. Sanatçının zengin taş ve ahşap işçiliği ile bezeli bu mekânı tüm detaylarıyla yansıtmış olması, büyük bir gözlem ve emeğin ürünüdür.

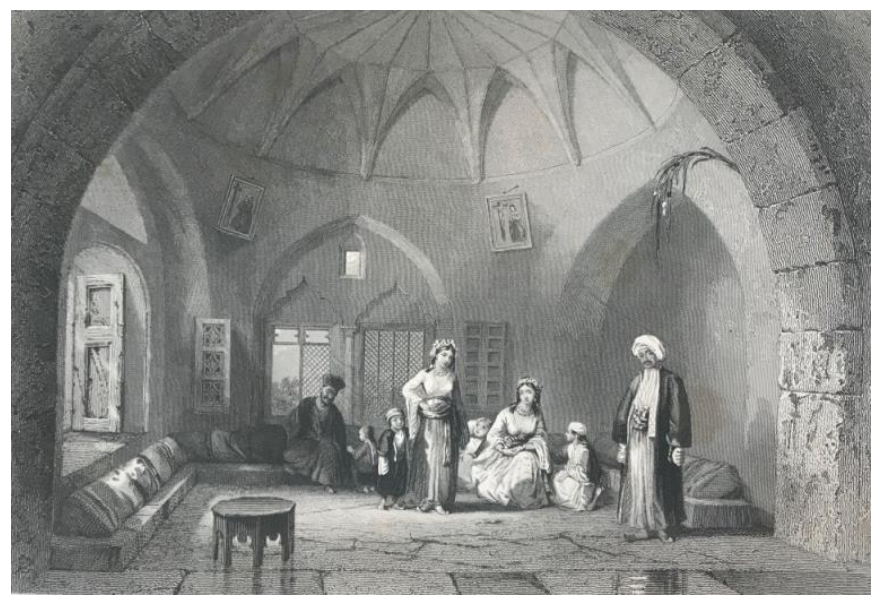

Foto. 26. William Henry Barlett'e ait olan Kudüs'te Bir Hristiyan Ailenin Evinin İçi (Stebbing, 1847:24) 
İçinde sivil mimari örneklerinin de yer aldığ 1 kentle ilgili gravürlerde, sokak dokusuyla birlikte 19. Yüzyıl Kudüs'ünün sosyal yaşamından kesitler yansıtılmıştır. Bunlardan Fenn'e ait Şam (Damascus) Kapısı Caddesi adlı gravürde, şehrin en işlek giriş noktalarından biri olan Şam Kapısı sokağı, kalabalık bir grup insanla birlikte verilmiştir (Foto. 27). Solda bir kahvenin önünde duran Bedeviler ve Osmanlı askerleri, sağda ise sebze ve meyve satıcıları görülmektedir. Tüm bu kalabalığın gerisinde ise kemerli kubbeli yapılar ile yıkık tonozlu sokaklar seçilmektedir. Gravür, hem sanatsal hem de belgesel açıdan önemli çalışmalardan biridir.

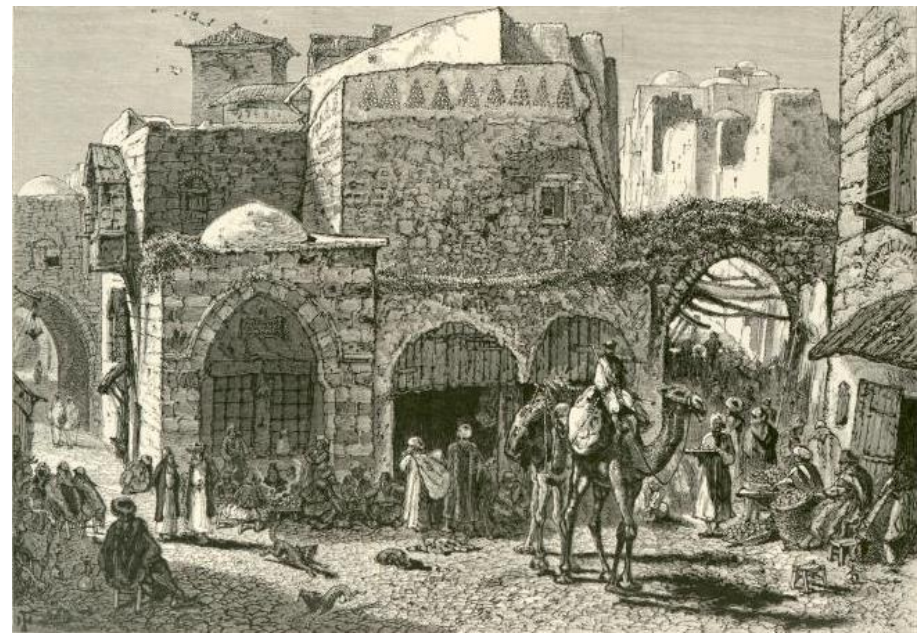

Foto. 27. Harry Fenn, Şam (Damascus) Kapısı Caddesi (Wilson, 1881: 40).

Gezgin sanatçı Fenn'e Sokak Kahvesi, Kudüs adlı diğer çalışmada, bir sokak kahvehanesinde bir bedevi ile köylünün dama oynamaları resmedilmiştir (Foto. 28). Gravür, ön planına yerleştirilmiş nargile, bedevinin elinde bulunan çubuk, Doğulu giysilere bürünmüş figürler ve harap durumdaki kahvehane ile oryantalist etkiler taşımaktadır. Tonozlu geçişe sahip sokak arasında iki figür daha görülmektedir. 


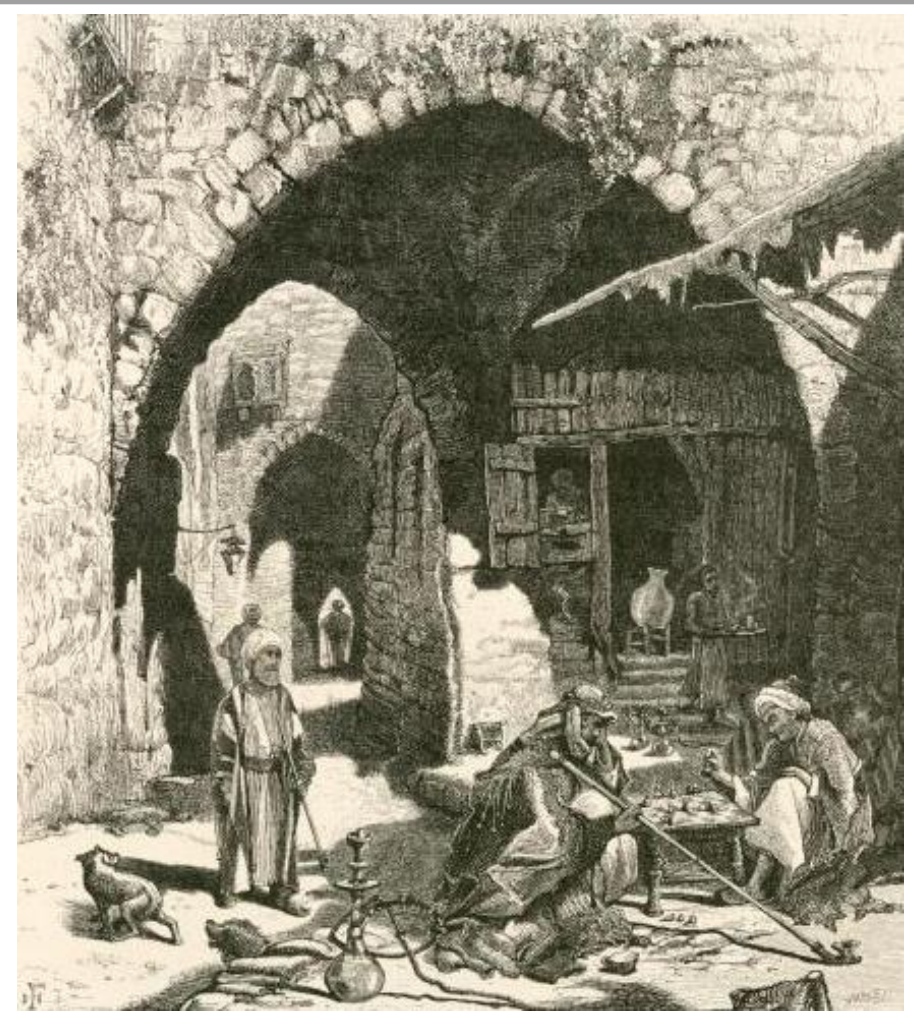

Foto. 28. Harry Fenn, Sokak Kahvesi, Kudüs, (Wilson, 1881: 33)

Kudüs sokaklarını gösteren diğer bir örnek, Woodward'a aittir. Bir ayakkabı dükkânının konu edildiği gravürde, Müslüman ayakkabıcılar çalışırken verilmiştir (Foto. 29).

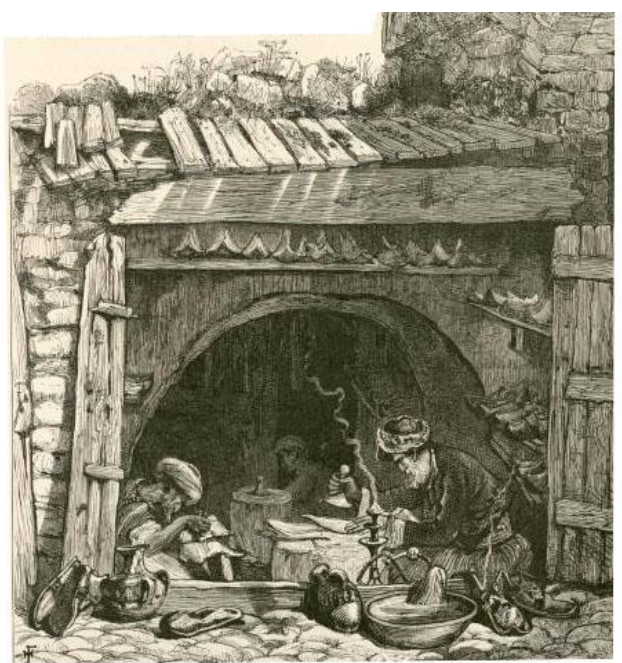

Foto. 29. J. D. Woodward, Ayakkabı Dükkânı, (Wilson, 1881: 27) 


\section{Sonuç}

Osmanlı İmparatorluğu'na seyahat eden gezgin ve sanatçılar, İmparatorluk sınırlarındaki birçok merkezi seyahatnamelerindeki anlatımlar ve bunları görselleştirdikleri gravürler ile Batı'ya taşımışlardır. Gravürlerde çok fazla yer verilen merkezlerden en önemlisi, kuşkusuz ki üç Semavi din için kutsal kabul edilen Kudüs’tür. Bu ilgide kentin taşıdığı dini ve kültürel anlamlar başat bir rol oynamaktadır. Kitab-1 Mukaddes'te anlatılan olayların büyük bölümünün bu topraklarda yaşanmış olması ve İncil'deki hikâyelerinin çoğunun bu topraklar üzerinde gerçekleşmesi, kenti değerli hale getirmektedir.

Önceki dönemlerde de ziyaret edilen kent, 19. yüzyılda aralarında Fransız, Alman, İspanyol ve İngiliz gibi farklı milletten çok sayıda sanatçıyı kendine çekmiştir. W. H. Bartlett, J. M. W. Turner, D. Roberts, T. Allom, J. D. Woodward gibi isimlerin bulunduğu İngiliz gezginler, kent ile ilgili olarak anlatımlara eşlik eden çok sayıda gravüre sahiptirler. Kentin tüm sokakları gezilmiş, daha önceden bilgi sahibi olunan dini olaylar ve bunların geçtiği mekânlar ziyaret edilmiştir. Öte yandan kentin mimarisi, sosyo-kültürel yapısı, günlük yaşamı vb. konular da yine ilgi alanları içindedir.

Uzun yolculukları sonrasında Kudüs'e ulaşan gezgin sanatçılar, öncelikle, kenti uzaktan ve panoramik görünümüyle algılarlar. Kentin stratejik konumu, dağ ve vadilerle çevrili oluşu ve ilginç yerleşim düzeni, burayı sanatçılar için resmedilmeye değer kılmıştır. Kent panoramaları özellikle, Zeytin Dağı ve kente girişte yer alan diğer yokuşlardan bakılarak çizilmiştir (Foto. 3-6).

Kudüs'e uğrayan gezginlerin kent ile ilgili gözlemlerinin ana temasını, Eski (Antik) Kudüs olarak bilinen kısım oluşturmaktadır. Bu görüntülerde kent surların gerisinde, Haremi Şerif'in içinde yer alan Mescid-i Aksa Camii ve Kubbet-üs Sahra gibi yapıların vurgulandığı kareler olarak verilmiştir (Foto 10). Genel görüntülerde vurgulanan bu binalar kentin mimari yapılarının ayrıntılı olarak ele alındığı örneklerde de karşımıza çıkmaktadır (Foto 11-13). Yapıların işlenişinde büyük bir titizlik ile çalışıldığı ve özellikle mimari öğeleri ile süslemelerinin ayrıntıcı bir biçimde yansıtılmaya çalışıldığı görülmektedir.

Sanatçıların Kudüs gözlemleri İncil'de konu edilen Zeytin Dağı ile başlayıp Hz. İsa'nın yaşamından izleri barındıran Getsemani Bahçesi, Via Dolorosa (Çile Yolu) gibi yerlerle devam etmektedir (Foto. 9, 18). İncil'in anlatımlarını takip eden bu serüvende en fazla ilgiyi kuşkusuz Kamame Kilisesi görmüştür. Yapı dış ve iç görünümleri ile izleyicisine büyük bir titizlikle sunulmuştur (Foto. 14-16).

Dini yapılar arasında Yahudiler'e ait olan ve Batı Duvarı olarak da bilinen Ağlama Duvarı en fazla ilgi görenlerden biridir (Foto. 20).

Kudüs'te dikkatlerden kaçmayan diğer bir yağı grubu kenti kuşatan surların giriş kapılarıdır. Şam Kapısı ve Altın Kapı gibi yapılar sanatçıların gravürlerine yansımıştır (Foto.21 23). Kentin su yapıları olan çeşme ve sebiller de işlenen diğer bir konudur (Foto. 24-25).

Kenti gezen sanatç1lar, sokak görüntülerinden ve burada gerçekleşen günlük hayattan sahneleri de gravürlerinde işlemişlerdir (Foto. 27-28)

Geniş bir konu perspektifine sahip olan gravürlerin çoğunlukla belgeleyici bir kaygıyla ele alındığı dikkat çekmektedir. Bununla birlikte bazı örneklerde abartılı ifadelere yer verildiği görülmektedir (Foto. 8). Ayrıca çalışmalarda Romantik ve Oryantalist eğilimler de dikkati çekmektedir (Foto. 7,12, 28). 


\section{KAYNAKÇA}

Akyol, Yunus Emre (2019), 19. Yüzyılın İkinci Yarısında Kudüs Kamame Kilisesi Üzerine Osmanlı Politikaları, Pamukkale Üniversitesi, Sosyal Bilimler Enstitüsü, Tarih Anabilim Dalı Yakınçağ Tarihi Programı, Basılmamış Yüksek Lisans Tezi, Denizli.

Arslan, Necla (1992), Gravür ve Seyahatnamelerde İstanbul (18. Yüzyıl Sonu ve 19. Yüzyıl), İstanbul: İstanbul Büyükşehir Belediyesi Kültür İşleri Daire Başkanlığı Yayınları. (Sevin) (2006), Gravürlerde Yaşayan Osmanl, Ankara: Kültür ve Turizm Bakanlığı Yayınları.

Cömert, Bedrettin (1999), Mitoloji ve İkonografi, Ankara: Ayraç Yayınevi.

Çift, Pelin- Harman, Ömer Faruk (2017), Kudüs'ün Gizemli Tarihi, İstanbul: Destek Yayınları.

Dağdelen, İrfan, (2018), Gravürlerle Kudüs, İstanbul: İstanbul Büyükşehir Belediyesi Kültür A.Ş. Yayınları.

Filistin Rehberi (t.y.), (Edt. Hamdan Taha- Wael Hamamra) http://www.tika.gov.tr/upload/2016/Prestij\%20Eserler/T\%C3\%BCrkce\%20Filistin\%20Reh beri.pdf Erişim Tarihi: 19.03.2018.

Germaner, Semra -İnankur, Zeynep (1989), Oryantalizm ve Türkiye, İstanbul: Türk Kültürüne

Hizmet Vakfi

Germaner, Semra (1992), "19. Yüzyılın İkinci Yarısında Osmanl1-Fransız Kültür İlişkileri ve Osman Hamdi Bey" 1. Osman Hamdi Bey Kongresi (2-5 Ekim 1990), İstanbul, 105-112. (2002), Oryantalistlerin İstanbulu, İstanbul: Türkiye İş Bankası Yayınları.

Güzel, Eylem (2010). Ege Bölgesi Kent Mimarisinin Seyahatname ve Gravürlere Yansimas1, Yüzüncü Yıl Üniversitesi, Sosyal Bilimler Enstitüsü, Sanat Tarihi Anabilim Dalı, Basılmamış Doktora Tezi, Van.

Harman, Ömer Faruk, (2002) .’Kudüs”, Türkiye Diyanet Vakfi İslam Ansiklopedisi, C.26. İstanbul: Türkiye Diyanet Vakfi Yayın Matbaacılık ve Ticaret İşletmesi, 323- 327.

Kabbani, Rana (1993), Avrupa'nın Doğu İmajı, (Çev. Serpil Tuncer), İstanbul: Bağlam Yayıncılık.

Kılıç, Sami- Satış, İhsan (2011), "Osmanlı Arşiv Vesikalarına Göre Hristiyan Cemaatlerin Kamame Kilisesi ile İlgili Tartışmaları”, History Studies, 3/3 2011, 225-244.

Kitabı Mukaddes (2000), İstanbul: Acar Matbaacılık.

Lancaster, James E., "Jerusalemin 19th Century Art" http://www.coastdaylight.com/prints/printc8129.html Erişim Tarihi: 24.02.2018.

Montefiore, Simon Sebag (2016). Kudüs, Bir Şehrin Biyografisi (Çev. C.Demirkan). İstanbul: Pegasus Yayınları.

Parla, Jale (2005), Efendilik, Şarkiyatçılık, Kölelik, İstanbul: İletişim Yayınları.

Ross, Alexander M (1973). William Henry Barlett Artist, Author \& Traveller, Canada: University of Toronto Press.

Satış, İhsan- Ceyhan, Muhammed (2012), "Kudüs'teki Rum Cemaatine Ait Bir Defter: 10 Numaralı (Kamame) Kilise Defteri" Belgeler, C. XXXIII- S. 37, Ankara, 2012 (Ankara 2014- Ayribasım), 21-55. 
Stebbing, Henry (1847), The Christian in Palestine; or, scenes of sacred history, historical and descriptive, London: George Virtue.

Tahman, M. Baha. "Üç Kitaplı Kentler, 19. Yüzyıl Fotoğraflarında Kudüs ve Kutsal Topraklar" https://artsandculture.google.com/exhibit/ARTP3HZa?hl=tr Erişim Tarihi: 15.02.2018).

Taşçıar, Bahar (2002), 16. Yüzyılda Batılı Gezginlerin İngilizce ve Türkçe Yayımlanan Notlarında İstanbul ve Anıtları, İstanbul Teknik Üniversitesi, Sosyal Bilimler Enstitüsü, Yayınlanmamış Yüksek Lisans Tezi, İstanbul.

Uğurluel, Talha (2017), Arzın Kapısı Kudüs Mescid-i Aksa, İstanbul: Timaş Yayınları.

Wilson, C. W. (1881), Picturesque Palestine, Sinai and Egypt. C.1, Newyork.

https://digitalcollections.nypl.org/items/510d47d9-5dbd-a3d9-e040-e00a18064a99 Erişim Tarihi: 15.02.2018

http://www.medinaarts.com/HF055.html- Erişim Tarihi: 15.02.2018

http://www.medinaarts.com/HF054.htm Erişim Tarihi: 15.02.2018

http://www.artnet.com/artists/thomas-allom/jerusalem-from-the-mount-of-olives-by-the-tomb-ofIwkXRCd5haUcmLeL5cqIBg2 Erişim Tarihi: 20.08.2019

https://www.tate.org.uk/art/artworks/turner-jerusalem-from-the-mount-of-olivest05167 Erişim Tarihi: 07.09.2019

https://www.tate.org.uk/art/artworks/turner-jerusalem-t04732 Erişim Tarihi: 07.09.2019

https://islamansiklopedisi.org.tr/aglama-duvari, Erişim Tarihi: 07.09.2019 